\title{
Carbonation resistance of concrete: limestone addition effect
}

\section{Abdurrahman A. Elgalhud}

Doctoral Researcher, University of Birmingham, Birmingham, UK; Assistant Lecturer, University of Tripoli, Tripoli, Libya

\section{Ravindra K. Dhir}

Professor, Concrete Engineering, University of Birmingham, Birmingham, UK (corresponding author: r.k.dhir@bham.ac.uk)
Gurmel S. Ghataora

Senior Lecturer, University of Birmingham, Birmingham, UK

Systematic analysis and evaluation of experimental results on carbonation and carbonation-induced corrosion resistance of concrete made with Portland limestone cement (PLC) are presented; these results have been extracted from 143 globally published studies in the literature since 1986, by 274 researchers from 131 institutions and 34 countries, and yielding a 19000 data matrix are presented. It is shown that the carbonation of concrete increases with increasing limestone content, within the range permitted by standard BS EN 197-1:2011. This effect, however, is less marked for concrete designed on an equal strength basis to the corresponding Portland cement (PC) concrete than concrete designed on an equal water/cement (w/c) basis. Eurocode 2 standard specifications for XC3 carbonation exposure for characteristic cube strength of concrete (or its $w / c$ ratio) may need to be reviewed for the addition of limestone. Other influencing factors: curing, limestone fineness, total cement content, were also studied. A comparison has been conducted for the carbonation performance of concrete made with PLC and cement containing fly ash and ground granulated blast-furnace slag. Procedures to reduce the carbonation of PLC concrete are proposed. Response to accelerated carbonation, at 3-5\% carbon dioxide concentration, of PLC concrete is similar to natural indoor exposure. A conversion factor of 1 week accelerated carbonation equal to 0.75 year natural indoor exposure was determined.

\section{Introduction}

Although historically the use of limestone (LS) as a construction material dates back to ancient times, when calcined LS or gypsum was used to make mortar (Mayfield, 1990) and when LS became one of the main constituents of the raw feed used to manufacture Portland cement clinker in 1824, it is the acceptance of LS as an addition to cement with Portland clinker (EN 197-1, 2000 (BSI, 2011)), to reduce the carbon footprint of concrete, that is offering new potential for the use of this material in concrete.

The first attempt at using LS as a component of cement was in 1965 in Germany, and later in 1979 the French Cement Standards allowed its use as an addition; this was followed by its adoption by various standards: the Canadian Standards in 1983 at 5\% addition, British Standards in 1992 up to $20 \%$ addition and European Standard EN 197-1 in 2000 as Portland LS cements CEM II/A-L and CEM II/B-L with LS content $6-20 \%$ and $21-35 \%$, respectively. Indeed, now the use of Portland limestone cement (PLC) has been adopted worldwide. This use is increasing on grounds of sustainability, enforcing reduction in energy and carbon dioxide emission associated with Portland cement (PC) manufacture (Tennis et al., 2011). In addition, among all cement addition materials, such as ground granulated blast-furnace slag (GGBS) and fly ash (FA), LS is the most widely available natural material, with calcium carbonate $\left(\mathrm{CaCO}_{3}\right)$ occupying $5 \%$ of the earth's crust (Thenepalli et al., 2015).

When LS is added to PC, it influences its properties both in the fresh and hardened states, as well the durability. Although the performance of PLC has been investigated widely in the past in terms of durability, the available information has remained fragmented and often unhelpful in further developing the use of PLC in concrete construction. Moreover, delivering sustainability in a meaningful manner demands compliance with required durability specifications in a cost-effective way.

The main aim of this paper, which is the third and the final in a series of papers, is to establish the potential resistance of PLC to carbonation and carbonation-induced corrosion of concrete and how this performance compares with the use of FA (Lye et al., 2015) and GGBS (Lye et al., 2016). To facilitate a meaningful performance comparison of the 
three additions, the paper has been formatted similarly to the two papers previously published in the Magazine of Concrete Research (Lye et al., 2015, 2016).

\section{Methodology adopted}

An extensive search of the published literature in English has been undertaken, using different databases and citation indices in order to ascertain the extent and nature of related research that has been undertaken and to obtain the available test data, arising from 34 countries and dating back to 1986. It was noted that the major contribution in this field has come from Europe (Figure 1).

The sourced literature was examined and divided into four major categories and other subcategories, as shown in Figure 2 and further explained below.

(a) Narrative review papers: these summarise the findings of the selected few studies and give conclusions. Although useful, such publications do not necessarily give the test information in any detail.

(b) Experimental results papers: these present and discuss the experimental data obtained from the dedicated projects undertaken.

(c) In situ measurement papers: these are studies undertaken on existing structures (new or old), which report the results of the tests undertaken on structural members in situ or the specimens cored from them. (d) Modelling papers: these represent theoretical work. The study presented in this paper does not include the results arising from modelling work.

(e) Portland composite cement mixtures: these consisted of additional cementitious materials to LS, such as GGBS, FA, silica fume (SF) and metakaolin (MK). Although these studies investigated carbonation of concrete with LS in conjunction with other additions, the results obtained made it difficult to clearly appreciate the role of LS addition and such data have been excluded from further consideration.

For the studies concerning carbonation depth/rate of PLC concrete, an additional breakdown was made, where some papers did not provide the results of the reference concrete mixes made with PC, and a few publications had duplicated data and were not considered further. The analyses of the data have been undertaken considering the type of carbonation exposure (accelerated or natural) and the type of cementitious mixture (paste and mortar/concrete). It should also be noted that in expressing water/cement ratio $(w / c)$, the word 'cement' refers to the whole combination of Portland cement clinker and LS.

\section{Overview of the literature}

Although limited in number, and without detailed analysis of the data, both the individual and organisation reviews (Table 1) suggest that there is consensus among these

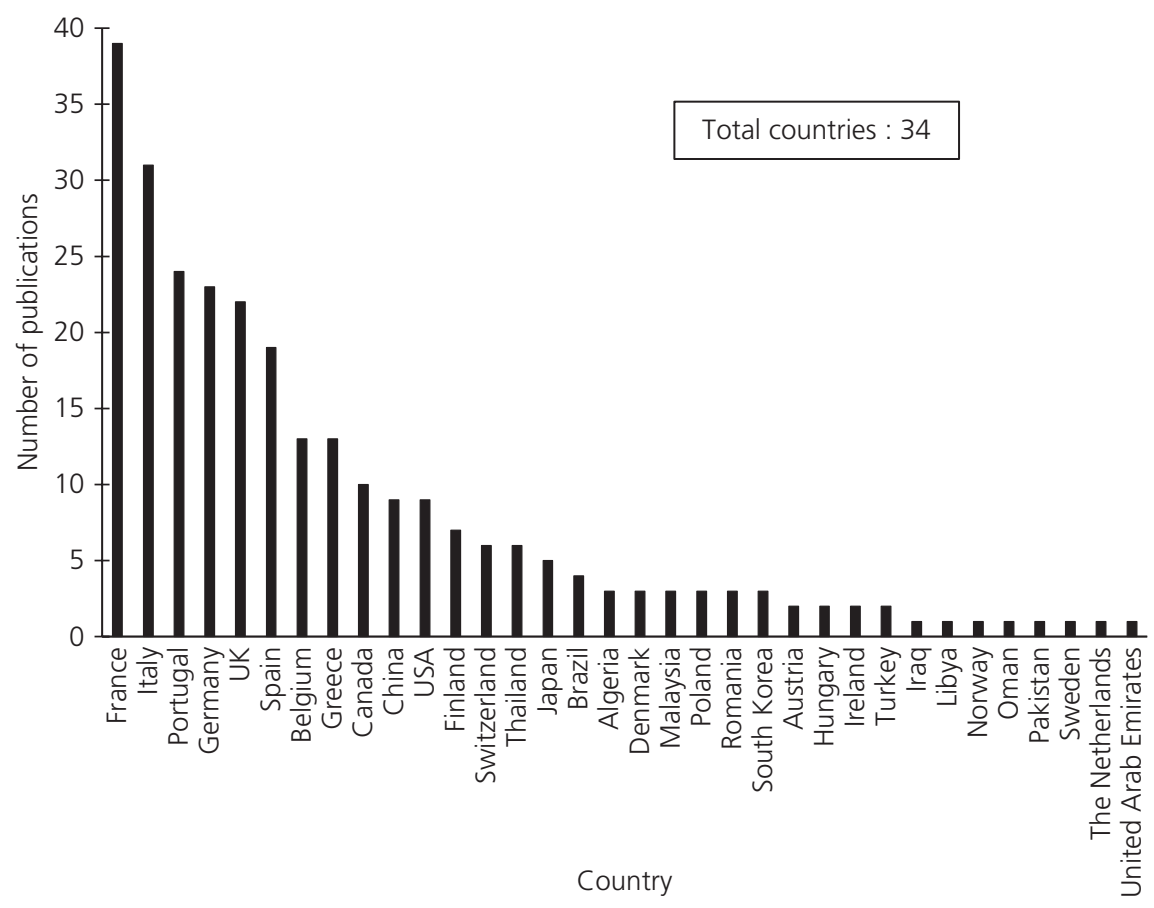

Figure 1. Country distribution for authors of the collected publications 


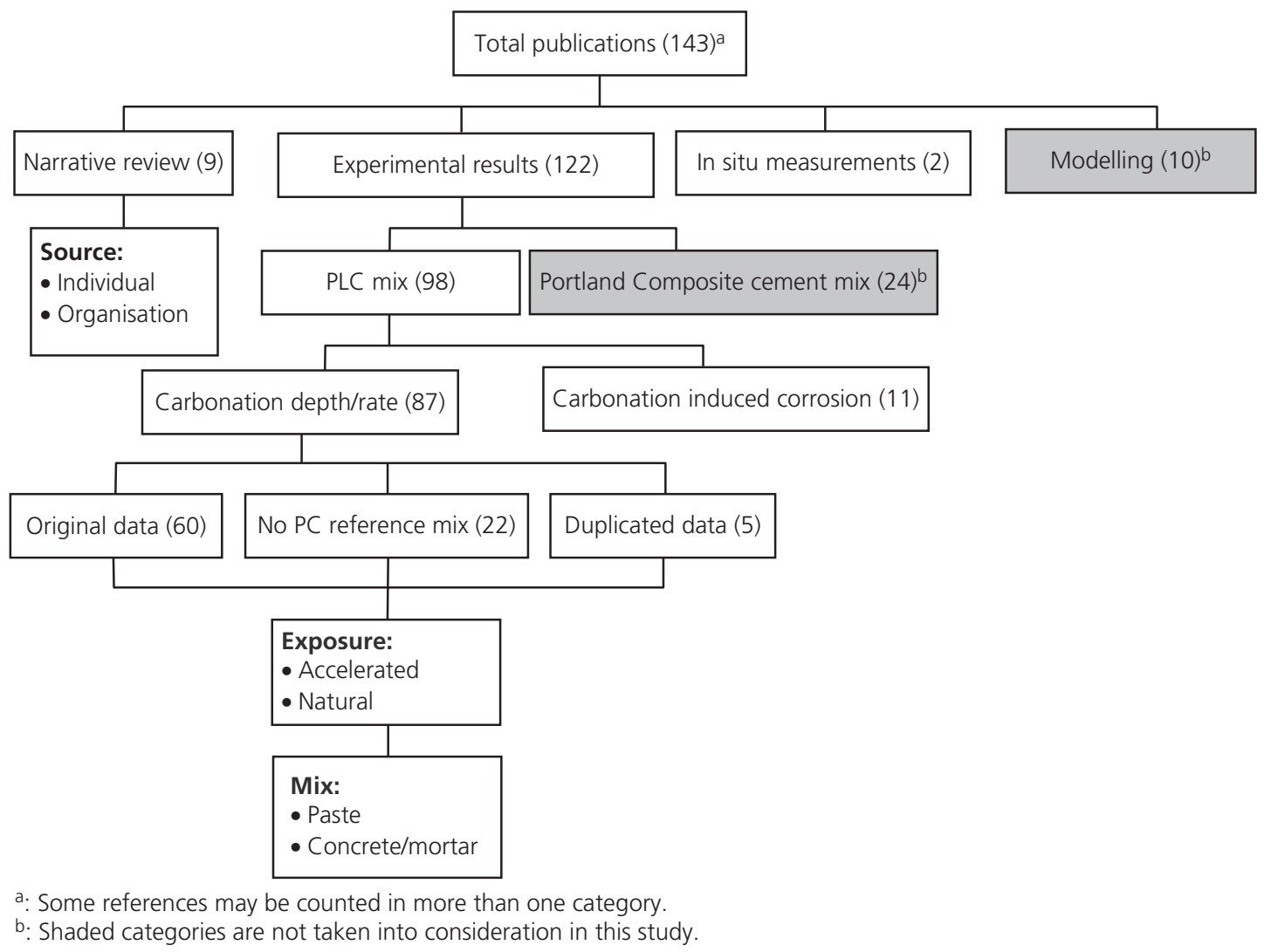

Figure 2. Flow chart showing the type of references found in the literature regarding the carbonation of PLC

reviewers that the carbonation resistance of concrete is not significantly altered with the addition of up to $15-20 \%$ LS (i.e. cements such as Portland-LS cement, CEM II/A in BS EN 197-1 (BSI, 2011)). However, the reviews provided by the national cement/concrete organisations in Canada, Sweden, UK and USA concluded that, at a given $w / c$ ratio, the use of LS addition as a cement component (i.e. the use of PLC as per BS EN 197-1 (BSI, 2011)) can potentially be expected to increase its carbonation, albeit in some cases, and up to a certain level of LS addition it may not be significant in the context of overall concrete mix variations. However, the mixes designed on an equal strength basis with PLC can be expected to carbonate at a similar rate to PC concrete.

On the other hand, the overview of the reported data relating to the effect of LS addition to PC on the carbonation of concrete (PLC concrete) subjected to both natural and accelerated exposures, as presented in Table 2, revealed that the vast majority of the results of the tested mixes $(76 \%)$ show that the inclusion of LS leads to a higher rate of concrete carbonation. In contrast, only $9 \%$ of the reported data suggest that the carbonation of PLC concrete can be lower than the corresponding PC concrete, with $3 \%$ indicating no change, and $4 \%$ showing a variable trend; for $8 \%$ of the reported results there were no corresponding PC concrete mixes tested, and therefore the PLC data could not be compared with the corresponding PC concrete mixes.

\section{Analysis of published data}

\section{Variation in the testing procedures used}

The test conditions employed in the reported studies to measure the effect of LS on the resistance of concrete to carbonation, using both accelerated and natural exposures, are summarised in Table 3. While the first impression can be that widely varying conditions have been applied to measure the carbonation resistance of both PC and PLC test concrete mixes, in reality the majority of the test parameters in general have been kept within an acceptable range. The main points emerging from Table 3 are listed below.

(a) Carbonation exposure. Surprisingly, natural exposure was adopted more than accelerated exposure in the testing of concrete for carbonation, in a ratio of 3 to 2 , and within this indoor exposure had been used the most.

(b) Specimen. Although the choice of test specimens in the form of cylinders, prisms and cubes appeared to be 


\begin{tabular}{|c|c|c|}
\hline Reference & $\begin{array}{l}\text { No. of cited } \\
\text { references }\end{array}$ & Main observation \\
\hline \multicolumn{3}{|l|}{ (a) Individual } \\
\hline Ayub et al. (2013) & 1 & $\begin{array}{l}\text { LS addition increases the carbonation rate in concrete, except } \\
\text { when the amount of cement replacement is } 15 \% \text { or less }\end{array}$ \\
\hline Müller (2012) & 1 & $\begin{array}{l}\text { The use of LS addition up to } 20 \% \text { could slightly increase the } \\
\text { carbonation depth }\end{array}$ \\
\hline Torgal et al. (2012) & 3 & $\begin{array}{l}\text { No considerable influence on carbonation resistance with LS } \\
\text { content up to } 15 \%\end{array}$ \\
\hline \multicolumn{3}{|l|}{ (b) Organisation } \\
\hline $\begin{array}{l}\text { Hooton et al. (2007); Cement Association } \\
\text { of Canada }\end{array}$ & 6 & LS has the potential to increase the carbonation of concrete \\
\hline $\begin{array}{l}\text { Lagerblad (2005); Swedish Cement and } \\
\text { Concrete Research Institute CBI, } \\
\text { Sweden }\end{array}$ & 1 & $\begin{array}{l}\text { PLC concrete will carbonate somewhat faster, as the amount of } \\
\text { Portland clinker cement paste and the buffering capacity is } \\
\text { less than in the corresponding PC concrete }\end{array}$ \\
\hline $\begin{array}{l}\text { Detwiler and Tennis (1996); Hawkins } \\
\text { et al. (2003); Portland Cement } \\
\text { Association, USA }\end{array}$ & 9 & $\begin{array}{l}\text { The literature review shows mixed results for PLC when } \\
\text { compared to PC. The differences are of limited practical } \\
\text { significance in the context of overall concrete mix variations }\end{array}$ \\
\hline $\begin{array}{l}\text { Tennis et al. (2011); Portland Cement } \\
\text { Association, USA }\end{array}$ & 6 & $\begin{array}{l}\text { PLC concrete will carbonate at a similar rate to PC concrete, } \\
\text { provided the concretes are designed for the same target } \\
\text { strength }\end{array}$ \\
\hline CSWP (2011); Concrete Society, UK & 2 & $\begin{array}{l}\text { PLC increases the rate of carbonation when concretes are } \\
\text { produced at a constant } W / C \text {; whereas PLC has similar } \\
\text { carbonation to PC when both concretes are designed to meet } \\
\text { an equal strength }\end{array}$ \\
\hline
\end{tabular}

Table 1. Summary of the findings of the narrative reviews in the literature regarding the carbonation of the PLC concrete

influenced by the relevant standard specifications adopted in a specific study, a large number of tests have been carried out using prisms. Moreover, in most cases information on how the specimens have been prepared for testing has not been provided. However, where declared, the majority of specimens were in the sealed form to allow for uniaxial directional carbonation.

(c) Curing. With the exception of some studies, and to a certain extent influenced by the local standard specifications, moist curing with relative humidity of $80-100 \%$, temperature of $20-30^{\circ} \mathrm{C}$ and duration of up to $28 \mathrm{~d}$ have generally been adopted.

(d) Pre-conditioning. Although this information was lacking in the majority of studies, where declared the commonly adopted treatment was carried out at a temperature of $20-30^{\circ} \mathrm{C}$, relative humidity of $45-85 \%$ and a duration of $14-28 \mathrm{~d}$.

(e) Accelerated and natural exposure conditions. The commonly used accelerated exposure consisted of a carbon dioxide concentration of up to $5 \%$, duration of $\leq 30 \mathrm{~d}$, temperature of $20-30^{\circ} \mathrm{C}$ and humidity of $61-80 \%$, whereas the natural indoor exposure was of a period of up to 5 years' duration.
( $f$ ) Measurement. The vast majority of the studies utilised a phenolphthalein indicator to measure the depth of carbonation; the remainder did not declare the measurement method employed.

\section{Limestone effect}

Given the large number of test parameters involved, as can be seen from Table 3, the effect of LS addition on the carbonation resistance of PLC concrete has been analysed in relative terms to the corresponding PC concrete (used as reference) and the results thus obtained are shown plotted in Figure 3, with the majority of the data population being within the 5-35\% LS replacement band. The scatter in the data is understandably high as their source is global and the variables involved are high. In developing Figure 3, some of the data were excluded from further consideration, as follows

- outliers at each LS replacement level using box and whiskers plots

where the corresponding value for reference PC concrete was not available

- excessively high relative values (greater than 200\%) resulting from low carbonation measurement were considered to be unrealistic 


\begin{tabular}{|c|c|c|c|c|}
\hline \multirow{2}{*}{$\begin{array}{l}\text { Observation }{ }^{a} \text { of carbonation } \\
\text { depth of LS mixes }\end{array}$} & \multirow[t]{2}{*}{ Main suggested causes } & \multicolumn{3}{|c|}{ Number of tested mixes } \\
\hline & & Accelerated & Natural & Total \\
\hline Higher (455) & Cement & & & \\
\hline \multirow{13}{*}{$\begin{array}{l}\text { Accelerated (155) } \\
\text { Natural (300) }\end{array}$} & Reduction of Portland cement clinker & 32 & 49 & 81 \\
\hline & $\begin{array}{l}\text { Limestone plays the role of a nucleation site } \\
\text { for calcium carbonate precipitation }\end{array}$ & 4 & 0 & 4 \\
\hline & Design & & & \\
\hline & Low cement content & 8 & 11 & 19 \\
\hline & Higher $w / c$ ratio & 10 & 12 & 22 \\
\hline & Insufficient curing & 17 & 29 & 46 \\
\hline & $\begin{array}{l}\text { High carbon dioxide concentration } \\
\text { Hardened properties }\end{array}$ & 2 & 0 & 2 \\
\hline & Reduction of calcium hydroxide & 12 & 19 & 31 \\
\hline & Higher porosity/Coarser pore structure & 24 & 35 & 59 \\
\hline & Higher permeability & 0 & 12 & 12 \\
\hline & Low strength & 6 & 9 & 15 \\
\hline & Reduction of alkalinity & 6 & 0 & 6 \\
\hline & Not given & 53 & 105 & 158 \\
\hline Lower (51) & Cement & & & \\
\hline \multicolumn{5}{|l|}{ Accelerated (21) } \\
\hline \multirow[t]{8}{*}{ Natural (30) } & Higher specific area of LS & 0 & 5 & 5 \\
\hline & Design & & & \\
\hline & Lower $w / c$ ratio & 2 & 2 & 4 \\
\hline & Sufficient curing & 2 & 3 & 5 \\
\hline & Higher strength & 1 & 2 & 3 \\
\hline & Hardened properties & & & \\
\hline & Lower porosity & 0 & 5 & 5 \\
\hline & Not given & 10 & 19 & 29 \\
\hline No change (16) & Equal strength & 0 & 4 & 4 \\
\hline Accelerated (8) & Low w/C & 1 & 0 & 1 \\
\hline Natural (8) & Not given & 7 & 4 & 11 \\
\hline \multicolumn{5}{|l|}{ Variable (25) } \\
\hline Accelerated (1) & Not given & 1 & 24 & 25 \\
\hline \multicolumn{5}{|l|}{ Natural (24) } \\
\hline \multicolumn{5}{|l|}{ No reference mixture (47) } \\
\hline Accelerated (34) & Not applicable & 34 & 13 & 47 \\
\hline Natural (13) & & & & \\
\hline
\end{tabular}

${ }^{a}$ Higher/lower/no change/variable carbonation depth of LS mixture with respect to corresponding reference PC mixture

Table 2. Suggested causes of carbonation phenomenon of PLC concrete from the literature

- results showing full carbonation of test specimens, as in such cases it was not possible to calculate the actual depth of carbonation.

The best-fit relationship presenting the effect of using LS on the carbonation of concrete for the mean values is also plotted in Figure 3, having a coefficient of correlation $R^{2}=0.9335$. The trend line shows that, as the addition of LS increases, the relative carbonation of concrete increases at an increasing rate. For simplicity of reference, the range of BS EN 197-1:2011 (BSI, 2011) common cements with LS addition has also been shown. It can be seen that, at $35 \%$ of LS addition (the maximum limit permitted in BS EN 197-1:2011 (BSI, 2011)), the carbonation of PLC concrete could be about $62 \%$ higher than the corresponding PC concrete, whereas at $5 \%$ LS inclusion carbonation of PLC 


\begin{tabular}{|c|c|c|c|c|c|c|c|c|}
\hline & Parameter & Variable & No. & & & Parameter & Variable & No. \\
\hline \multirow[t]{7}{*}{ 1. Carbonation } & Accelerated & - & 219 & \multirow{7}{*}{\multicolumn{2}{|c|}{ 2. Specimen }} & \multirow[t]{4}{*}{ Specimen (594) } & Cylinder & 143 \\
\hline & (219) & & & & & & Prism & 307 \\
\hline & \multirow{5}{*}{$\begin{array}{r}\text { Natural } \\
(375)\end{array}$} & Indoor & 200 & & & & Cube & 128 \\
\hline & & $\begin{array}{l}\text { Outdoor, } \\
\text { sheltered }\end{array}$ & 132 & & & & Not given & 16 \\
\hline & & $\begin{array}{l}\text { Outdoor, } \\
\text { unsheltered }\end{array}$ & 18 & & & \multirow[t]{3}{*}{ Preparation (594) } & Sealed & 116 \\
\hline & & $\begin{array}{l}\text { Outdoor, } \\
\text { not given }\end{array}$ & 10 & & & & Unsealed & 22 \\
\hline & & Not given & 15 & & & & Unspecified & 456 \\
\hline \multirow[t]{14}{*}{ 3. Curing } & \multirow{3}{*}{$\begin{array}{l}\text { Exposure } \\
(594)\end{array}$} & Moist & 499 & \multirow{14}{*}{\multicolumn{2}{|c|}{ 4. Pre-conditioning }} & \multirow[t]{3}{*}{ Preparation (594) } & Omitted & 12 \\
\hline & & Air & 45 & & & & Applied & 226 \\
\hline & & Not given & 50 & & & & Not given & 356 \\
\hline & \multirow{5}{*}{$\begin{array}{l}\text { Duration: } \\
\text { d (594) }\end{array}$} & $1-14$ & 327 & & & \multirow[t]{4}{*}{ Duration: d (226) } & $1-7$ & 39 \\
\hline & & $15-28$ & 166 & & & & $14-28$ & 115 \\
\hline & & $56-91$ & 40 & & & & $76-351$ & 45 \\
\hline & & $>91$ & 7 & & & & Not given & 27 \\
\hline & & Not given & 54 & & & \multirow[t]{4}{*}{ Temperature: ${ }^{\circ} \mathrm{C}(226)^{\mathrm{a}}$} & $20-30$ & 169 \\
\hline & \multirow{3}{*}{$\begin{array}{l}\text { Temperature: } \\
{ }^{\circ} \mathrm{C} \text { (594) }\end{array}$} & $20-30$ & 522 & & & & $35-80$ & 43 \\
\hline & & $>30$ & 3 & & & & Not given & 14 \\
\hline & & Not given & 69 & & & & & \\
\hline & \multirow{3}{*}{$\begin{array}{l}\text { Humidity: } \\
\text { \% (594) }\end{array}$} & $80-100$ & 485 & & & \multirow[t]{3}{*}{ Humidity: \% (226) } & $45-85$ & 186 \\
\hline & & $40-80$ & 37 & & & & Not given & 40 \\
\hline & & Not given & 72 & & & & & \\
\hline \multirow{18}{*}{$\begin{array}{l}5 \text { (a). Accelerated } \\
\text { exposure } \\
\text { conditions }\end{array}$} & \multirow{5}{*}{$\begin{array}{l}\text { Carbon dioxide: } \\
\%(219)\end{array}$} & $<3$ & 48 & \multirow{18}{*}{$\begin{array}{l}5 \text { (b). Natural } \\
\text { exposure } \\
\text { conditions }\end{array}$} & \multirow[t]{5}{*}{ Indoor } & \multirow[t]{2}{*}{ Duration: years (200) } & $<1$ & 92 \\
\hline & & $3-5$ & 90 & & & & $1-5$ & 108 \\
\hline & & $6-10$ & 10 & & & \multirow[t]{3}{*}{ Temperature: ${ }^{\circ} \mathrm{C}(200)$} & $20-25$ & 192 \\
\hline & & $20-100$ & 68 & & & & Not given & 8 \\
\hline & & Not given & 3 & & & & & \\
\hline & \multirow{5}{*}{$\begin{array}{r}\text { Duration: } \\
\text { d (219) }\end{array}$} & $\leq 30$ & 131 & & & \multirow[t]{2}{*}{ Humidity: \% (200) } & $40-65$ & 189 \\
\hline & & $31-90$ & 53 & & & & Not given & 11 \\
\hline & & $91-180$ & 13 & & Outdoor & \multirow{3}{*}{$\begin{array}{l}\text { Sheltered, duration: } \\
\text { years (132) }\end{array}$} & $<1$ & 48 \\
\hline & & $>180$ & 21 & & & & $1-3$ & 47 \\
\hline & & Not given & 1 & & & & $4-9$ & 37 \\
\hline & \multirow{4}{*}{$\begin{array}{l}\text { Temperature: } \\
{ }^{\circ} \mathrm{C}(219)\end{array}$} & $<20$ & 1 & & & Unsheltered, duration: & $<1$ & 12 \\
\hline & & $20-30$ & 203 & & & years (18) & $1-4$ & 6 \\
\hline & & $>30$ & 10 & & & & & \\
\hline & & Not given & 5 & & & Unspecified, duration: & $\leq 1$ & 10 \\
\hline & Humidity: & $<50$ & 6 & & & years (10) & & \\
\hline & $\%(219)$ & $50-60$ & 49 & & & & & \\
\hline & & $61-80$ & 159 & & Not given & Duration: years (15) & $\leq 1$ & 15 \\
\hline & & Not given & 5 & & & & & \\
\hline
\end{tabular}

Note: Number in parenthesis is the sum of tested mixes in each individual parameter

${ }^{a}$ Data compiled from studies where pre-conditioning is applied

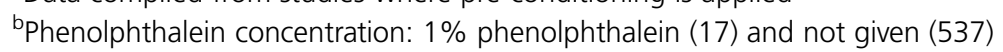

Table 3. Compilation of test parameters of carbonation

measurement in the literature 


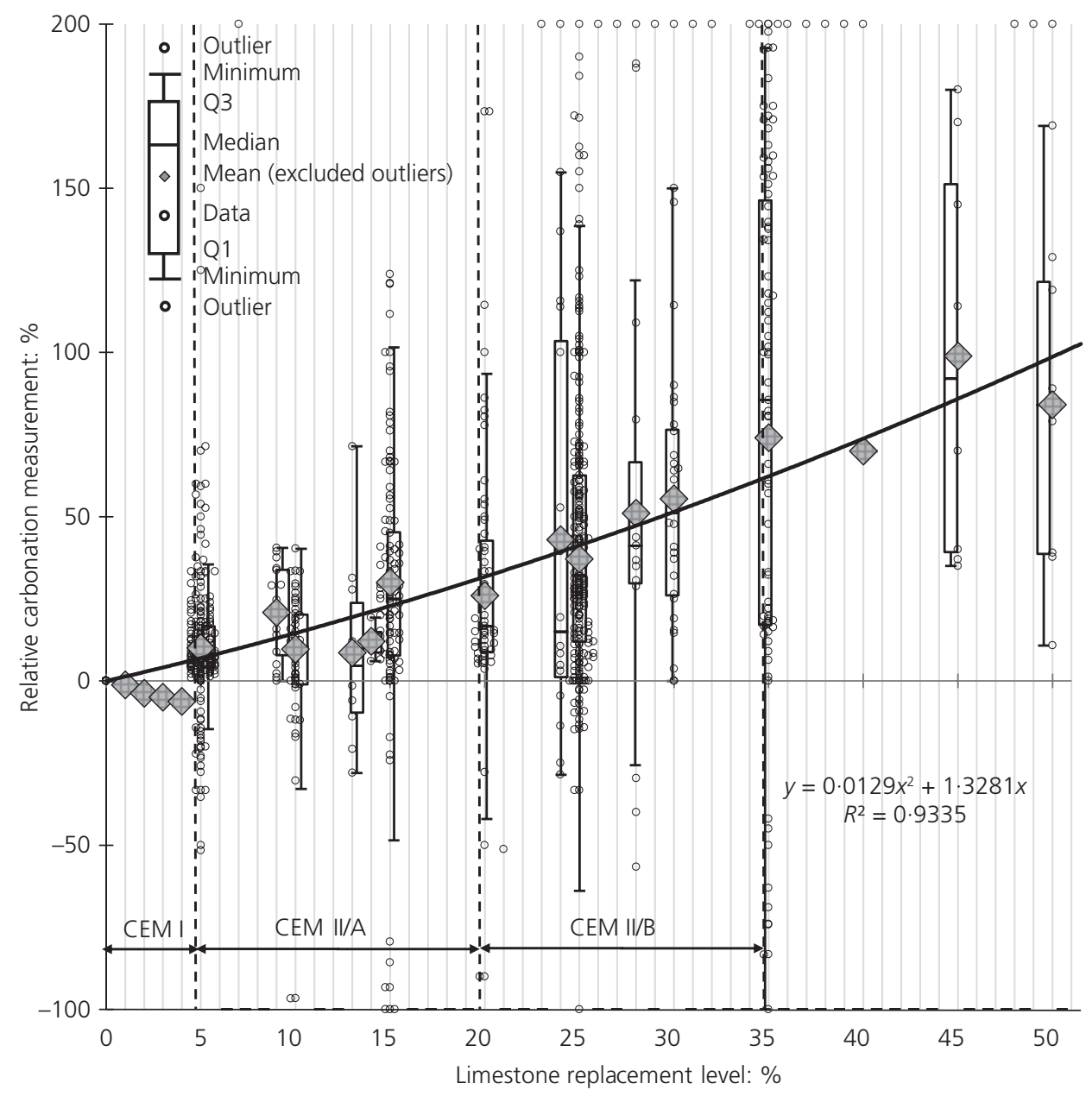

Figure 3. Limestone addition effect on carbonation resistance of concrete. Data of Figure 3 taken from: Abualgasem et al. (2014); Ali and Dunster (1998); Alunno-Rosetti and Curcio (1997); Balayssac et al. (1995); Balcu et al. (2012); Barker and Matthews (1994); Baron (1986); Batic et al. (2013); Bertolini et al. (2007, 2009); Bertrandy and Poitevin (1991); Cangiano and Princigallo (2010); Catinaud et al. (2000); Chowaniec and Scrivener (1992); Collepardi et al. (2004a); Courard et al. (2005); Courard and Michel (2014); Dhir et al. (2004, 2007); Drouet et al. (2010); El-Hassan and Shao (2015); Galan et al. (2010a, 2010b, 2012); Holt et al. (2009, 2010); Hussain et al. (2013); Ingram and Daugherty (1992); Kaewmanee and Tangtermsirikul (2014); Kargol et al. (2013); Kjellsen et al. (2005); Kuosa et al. (2008,
2012, 2014); Krell (1989); Leemann et al. (2015); Livesey (1991); Lollini et al. (2014); Manns et al. (2001); Marques et al. (2013); Meddah et al. (2014); Moir and Kelham (1993, 1999); Matthews (1994); Neves et al. (2015); Pomeroy (1993); Müller and Lang (2006); Müller et al. (2014); Mwaluwinga et al. (1997); Nielsen et al. (2014); Parrott (1994, 1996); Phung et al. (2015); Proske et al. (2013, 2014); Rabehi et al. (2013); Ranc et al. (1991); Rozière and Loukili (2011); Schmidt (1992a, 1992b); Schmidt et al. (1993); Shi et al. (2015); Silva and de Brito (2016); Sprung and Siebel (1991); Rostami et al. (2012); Shao et al. (2014); Tezuka et al. (1992); Thomas and Hooton (2010); Thomas et al. (2013); Tsivilis et al. (2000, 2002); Vandanjon et al. (2003). concrete could easily be assumed to be comparable to that of PC concrete.

\section{Influence of strength and $w / c$ ratio}

The results plotted in Figure 3 are separated in terms of $28 \mathrm{~d}$ strength and $w / c$ ratio within natural and accelerated exposures and are shown plotted on the basis of

- equal strength, in Figures 4(a) and 4(b).

- equal $w / c$ ratio, in Figures 5(a) and 5(b).
These figures show the following points.

- The effect of PLC on the carbonation of concrete at equal strength, as to be expected, is less marked than at equal $w / c$ ratio, showing at $35 \% \mathrm{LS}$ content for natural exposure an increase of 32\% (Figure 4(a)) and 75\% (Figure 5(a)), respectively.

- Accelerated carbonation gives rise to higher carbonation compared with natural exposure up to $58 \%$ on equal concrete strength basis (Figures 4(a) and 4(b)) and $85 \%$ 


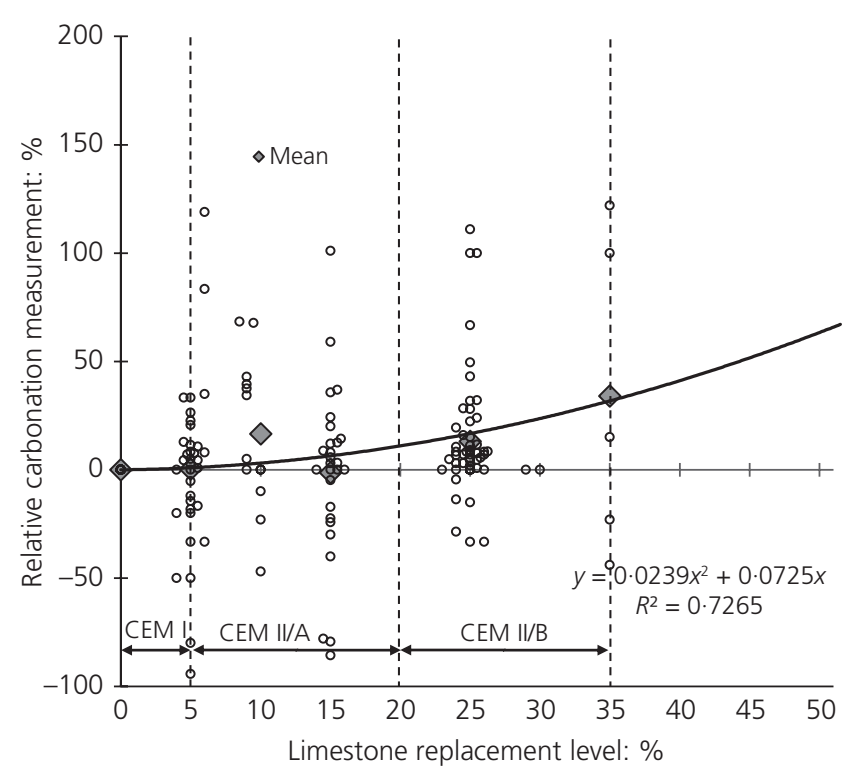

(a)

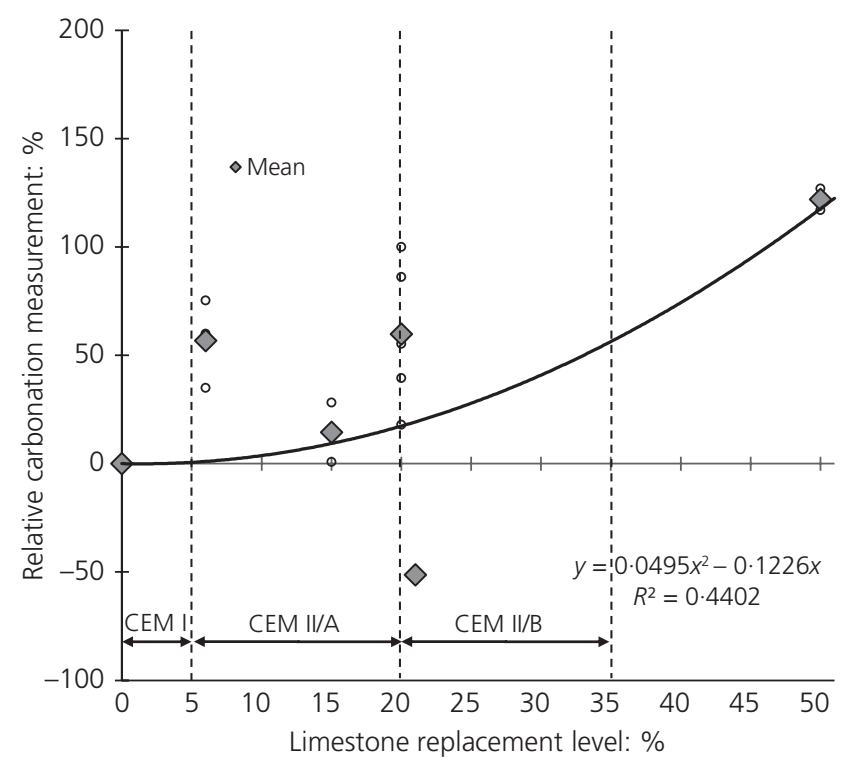

(b)

Figure 4. Influence of LS on carbonation resistance of concrete at equal $28 \mathrm{~d}$ strength for (a) natural and (b) accelerated carbonation exposures

on the basis of equal concrete $w / c$ ratio (Figures 5(a) and $5(\mathrm{~b}))$.

- When concrete mixes are designed on an equal strength basis, an addition of up to $10 \%$ of LS can be absorbed without giving rise to an increase in the carbonation of concrete. This facility is not available when the mixes are designed on an equal $w / c$ ratio basis.

\section{Influence of limestone fineness}

The effect of LS fineness on the carbonation resistance of PLC concrete, although of interest, has not been widely

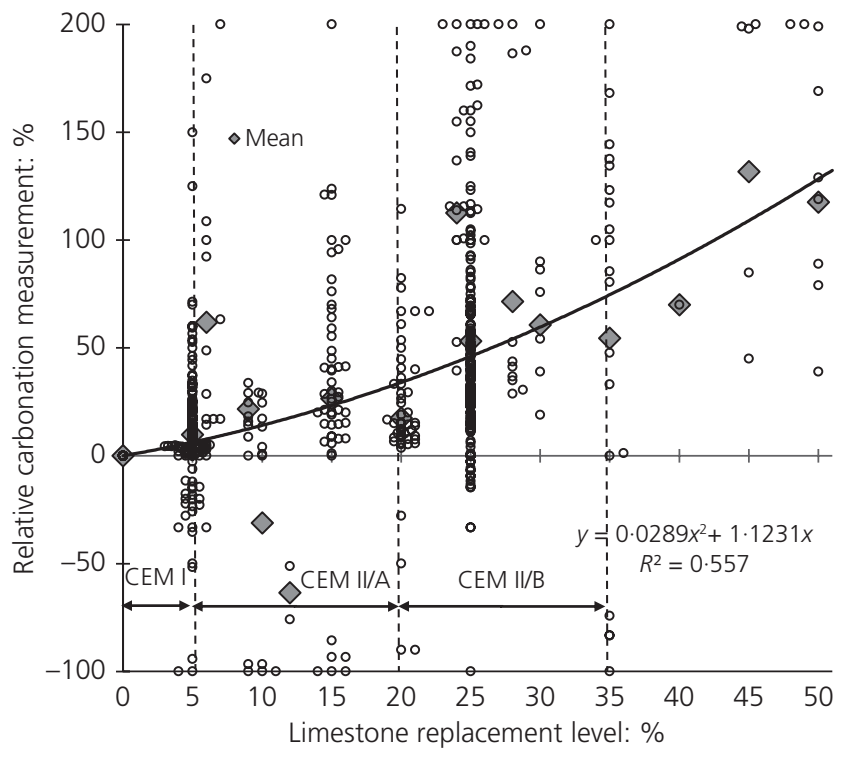

(a)

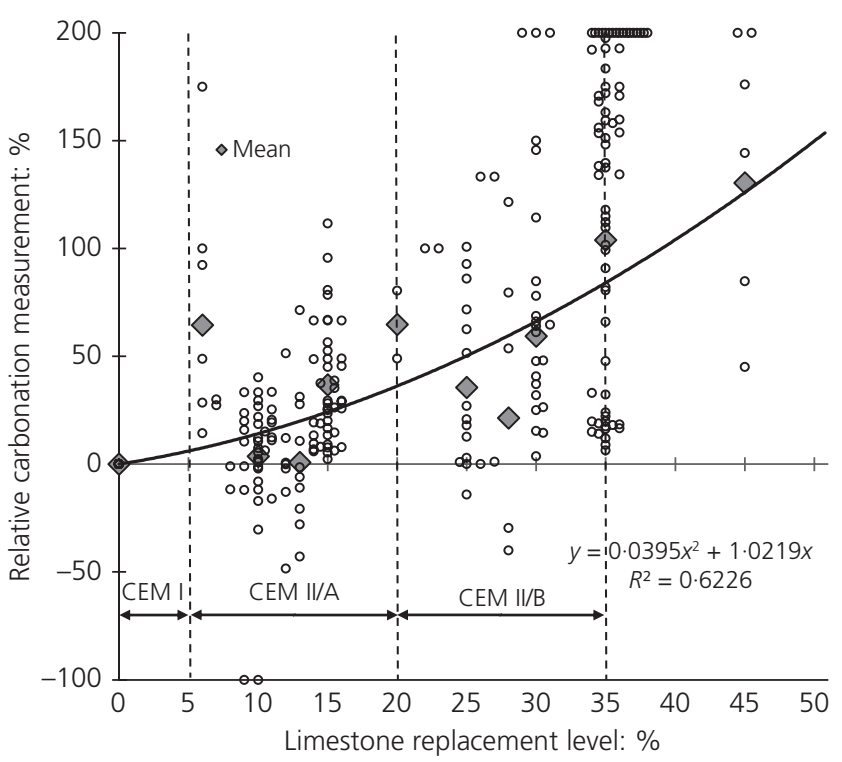

(b)

Figure 5. Influence of LS on carbonation resistance of concrete at equal $w / c$ ratio for (a) natural and (b) accelerated carbonation exposures

reported. The tests reported by Kaewmanee and Tangtermsirikul (2014) using mortar mixes containing only $10 \%$ LS of Blaine fineness essentially similar to that of PC (3320 and $3430 \mathrm{~cm}^{2} / \mathrm{g}$, respectively) showed an increase in carbonation depth of $30 \%$, and increasing the fineness of LS from 3320 to $9260 \mathrm{~m}^{2} / \mathrm{g}$ reduced the difference to $25 \%$ only, suggesting that increasing the fineness of LS more than that of $\mathrm{PC}$ is not a viable solution for controlling the carbonation of PLC concrete. 


\section{Influence of cement content}

Although not exhaustively, the effect of cement content on the carbonation of concrete has been examined over the cement range of $240-390 \mathrm{~kg} / \mathrm{m}^{3}$, with LS content of $15-30 \%$ and constant $w / c$ ratios of $0 \cdot 46-0 \cdot 65$, using accelerated carbonation exposure under the following conditions: moist curing for $28 \mathrm{~d}$; temperature of $20^{\circ} \mathrm{C}$; relative humidity of $55-65 \%$; carbon dioxide concentration of 2-5\%; exposure duration up to $140 \mathrm{~d}$ (Dhir et al., 2004; Lollini et al., 2014; Marques et al., 2013).

The results obtained are shown plotted in Figure 6. Although the data are few, and at times appear to be conflicting, there is sufficient evidence to suggest that the carbonation of both concretes decreases at a slow rate with increasing cement content, PC or PLC.

\section{Influence of curing}

\section{Curing conditions}

The study of the effect of curing on the carbonation of PLC concrete with $w / c$ ratio varying from 0.45 to $0 \cdot 76$, LS content up to $35 \%$, has been limited to moist and air curing for a period of $28 \mathrm{~d}$. Two types of exposure conditions employed were accelerated with temperature $20 / 30^{\circ} \mathrm{C}$, relative humidity $60 / 65 \%$ and carbon dioxide concentration $50 / 4 \%$ with test duration of $28 / 91 \mathrm{~d}$, respectively, by Rabehi et al. (2013) and Hussain et al. (2013) and natural indoor and outdoor shelter for a duration of 1, 4 and 9 years, respectively, by Baron

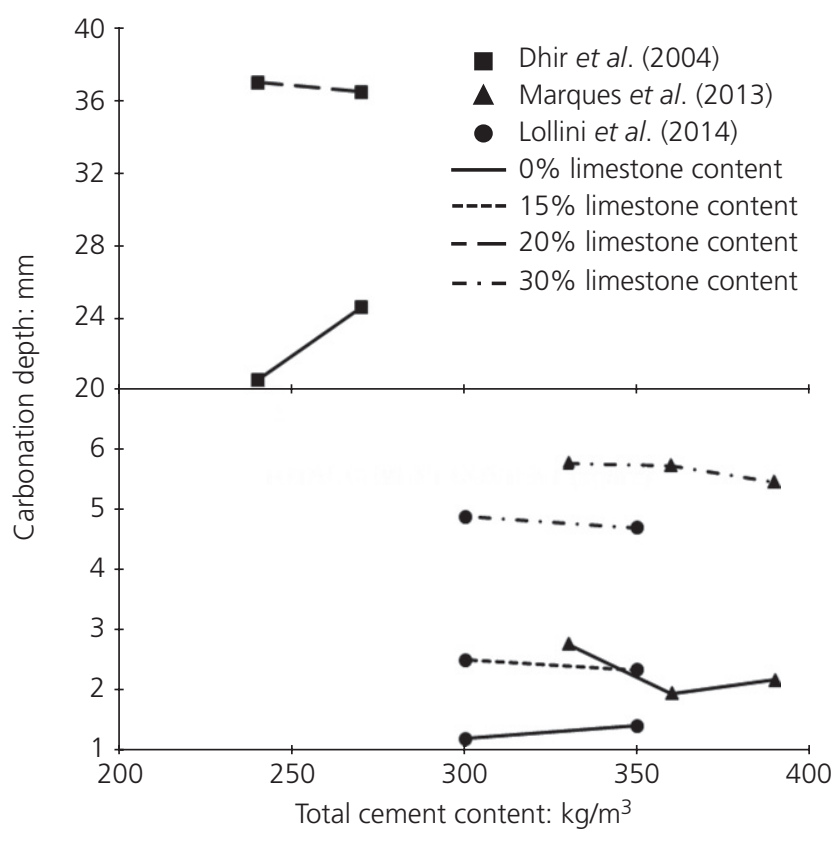

Figure 6. Influence of cement content on carbonation depth of PLC concrete exposed to accelerated carbonation
(1986), Ranc et al. (1991) and Ali and Dunster (1998). These studies showed, in general terms, that although the carbonation of both sets of concrete increased with the air curing of the test specimens, the PLC concrete relative to PC concrete did so at an increased rate that increased with LS content. The accelerated exposure produced higher carbonation than natural exposure, with the difference between the two widening with LS content.

\section{Curing duration}

The influence of curing duration on the carbonation resistance of PLC concrete has been studied with LS contents of $0-35 \%$, for a duration of $1-365 \mathrm{~d}$ and at a temperature of 20 and $30^{\circ} \mathrm{C}$, under both accelerated $(2,5$ and $50 \%$ carbon dioxide concentration) by Lollini et al. (2014), Rabehi et al. (2013) and Marques et al. (2013), and natural exposure conditions (indoor and outdoor sheltered) by Balayssac et al. (1995), Barker and Matthews (1994), Matthews (1994), Moir and Kelham (1993, 1999), Parrott (1996) and Thomas et al. (2013). The carbonation resistance of concrete, measured both in accelerated and natural exposures, improves with moist curing duration, particularly with initial moist curing. Although PLC concrete mixes give higher carbonation values than PC concrete, the difference between the two decreases with time, and does so more when the LS content is less than $15 \%$ and the mixes are designed on an equal strength basis.

\section{Carbonation depth with strength grade of concrete}

To envisage the provision of adequate concrete cover to reinforcement of PLC concretes, the obtained results are analysed in terms of carbonation depth and compressive strength. Taking 50 years as the design working life, category 4 for building structures and other common structures as specified in Eurocode 0 (BS EN 1990:2002+A1:2005 (BSI, 2002)), the expected carbonation depth data of concrete are shown plotted against $28 \mathrm{~d}$ characteristic cube strength for different natural exposure conditions, namely, $(a)$ indoor, $(b)$ outdoor sheltered and $(c)$ outdoor unsheltered, in Figure 7.

Figure 7 has been established as outlined below.

- The data used are taken from Figure 3 and in addition the carbonation data of those PLC mixes for which PC control mixes were not adopted by the authors (Assie et al., 2006, 2007; Bertolini et al., 2008; Bolzoni et al., 2006, 2014; Corinaldesi and Moriconi, 2004; Diamanti et al., 2013; Figueiras et al., 2009; Franzoni et al., 2013; Frazão et al., 2015a, 2015b; McNally and Sheils, 2012; Meira et al., 2014; Nieuwoudt et al., 2012; Owsiak and Grzmil, 2015; Perlot et al., 2013; Redaelli and Bertolini, 2011a, 2011b, 2014; Révay and Gável, 2003; Rio et al., 2015; Segura et al., 2013; Sistonen et al., 2008; Thienel and Beuntner, 2012; Tschegg et al., 2011; 


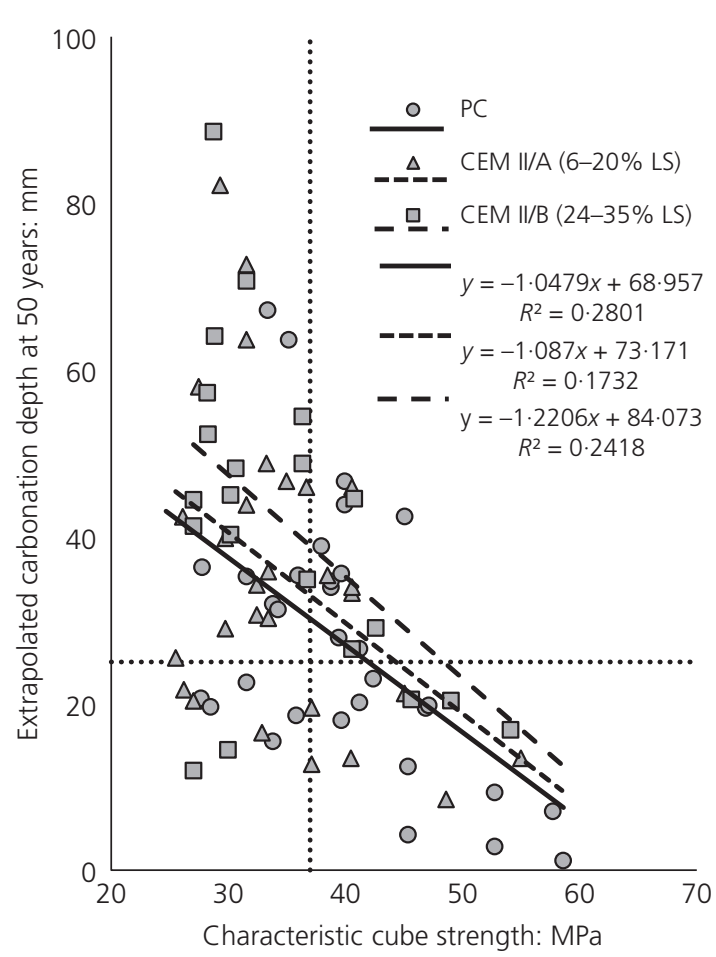

(a)

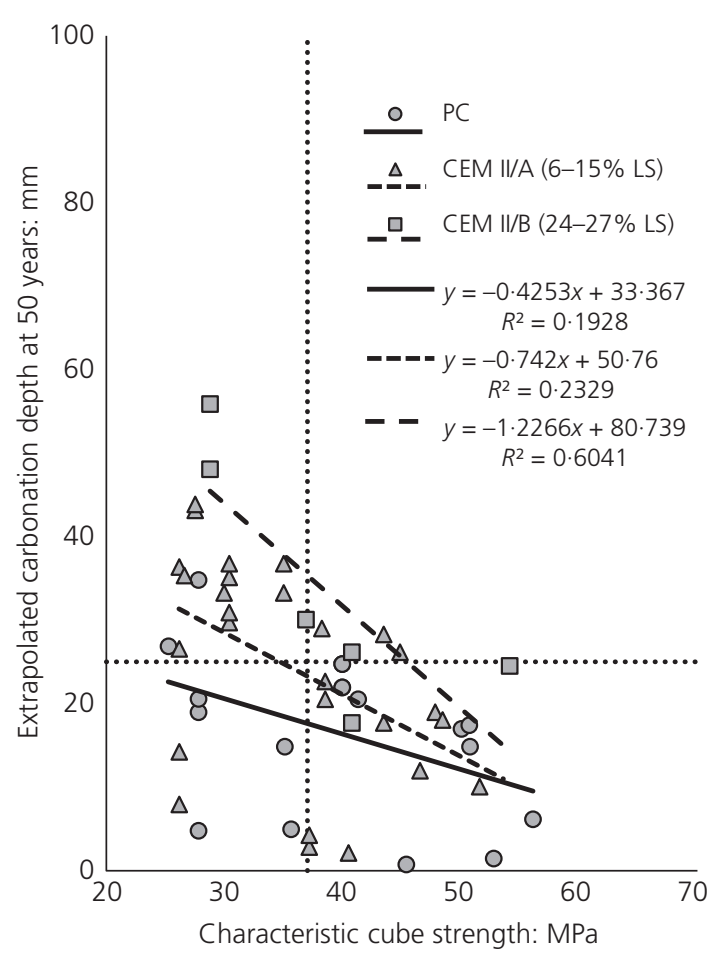

(b)

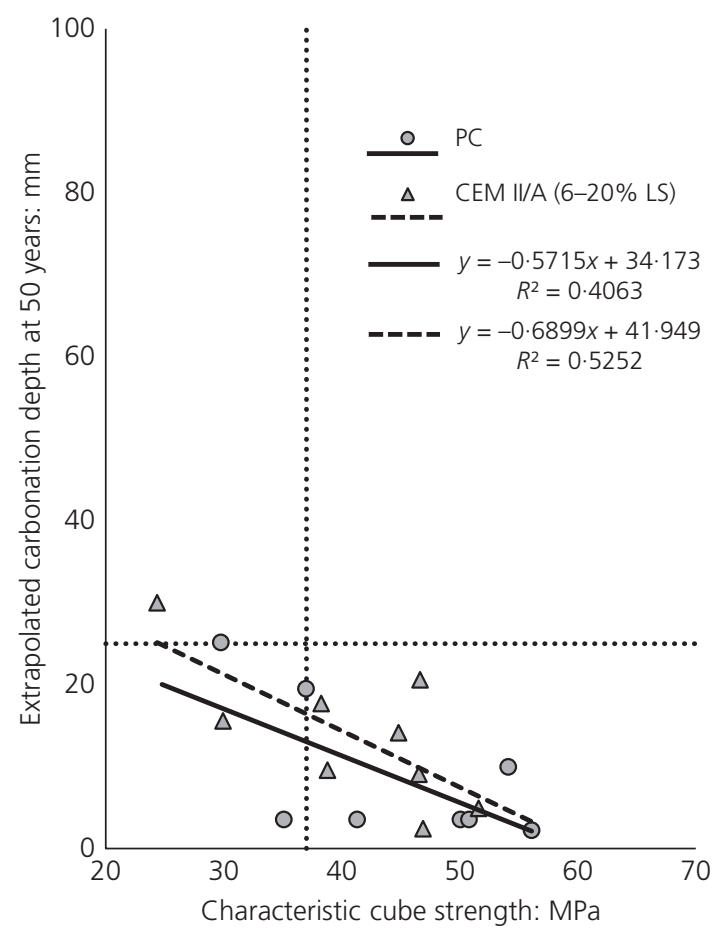

(c)

Figure 7. Extrapolated carbonation depth at 50 years of PC and PLC concretes subjected to natural carbonation exposures:

(a) indoor; (b) outdoor sheltered; (c) outdoor unsheltered, at different characteristic cube strengths 
Ylmen and Jäglid, 2013) have also been incorporated for this exercise.

- Where the ultimate figure for carbonation was given as zero by the authors, such studies have been ruled out from the analysis in this case.

- The predictable carbonation depth data at 50 years $\left(D_{50}\right)$ were determined based on Fick's law, $D_{50}=K \times t^{0.5}$, where $K$ is the rate of carbonation ( $\mathrm{mm} /$ year $^{0.5}$ ) and $t=50$ years. The value of $K$ used was as provided by the authors or alternatively calculated by employing the final carbonation depth data given by the authors.

- Characteristic cube strength has been determined using a variation coefficient of 6\% given in ACI 301:2005 (ACI, 2005) for fair laboratory control class.

- The data provided by the authors where the test mixes did not comply with the BS EN 206:2013 (BSI, 2013) mix limitations for the carbonation class $\mathrm{XC}$ were also not considered in this case.

As seen from Figure 7, the highest carbonation depths were for the indoor exposure and the lowest for the outdoor unsheltered exposure, with carbonation depth increasing with decreasing compressive strength and increasing LS content. Additionally, and important to this study, the following observations can be noted.

- For the indoor exposure, the 50 year estimated carbonation depths of both PC and PLC concretes surpass the minimum concrete cover specified in Eurocode 2 (BS EN 1992-1-1:2004+A1:2014 (BSI, 2004)) for the minimum cube compressive strength of $37 \mathrm{MPa}$ for exposure class XC3 (Figure 7(a)).

- For the outdoor sheltered exposure, the 50 year expected carbonation depths of PC and PLC (CEM II/A) concretes are below $25 \mathrm{~mm}$, whereas concrete with PLC (CEM II/B) has a carbonation depth greater than the minimum cover requirement (Figure 7(b)).
In the case of the outdoor unsheltered exposure, although the amount of data is comparatively small, the 50 year carbonation depths of both PC and PLC (CEM II/A) concretes are below $25 \mathrm{~mm}$, with the latter being higher than the former (Figure 7(c)).

Figure 7 also proposes how to obtain a carbonation of PLC concrete comparable to that of PC concrete. Using the carbonation of PC concrete at $37 \mathrm{MPa}$, as an example, subjected to indoor and outdoor sheltered conditions, to attain a similar carbonation to PC concrete, the compressive strength of PLC concrete would have to be increased on average by about 5.5 MPa and 10.5 MPa for CEM II/A (6-20\% LS) and CEM II/B (21-35\% LS) cements, respectively (Table 4).

In addition, Table 4 columns (a) and (b) summarises, for the indoor and outdoor sheltered exposures

(a) estimated carbonation depth corresponding to $37 \mathrm{MPa}$

(b) characteristic cube strength corresponding to $25 \mathrm{~mm}$ cover of concrete made with combinations of PC and different LS contents, such as those covered by BS EN 197-1:2011 (BSI, 2011).

The accelerated carbonation data pertaining to $3-5 \%$ carbon dioxide exposure were analysed in a similar way to the natural indoor exposure conditions shown plotted in Figure 7(a). This showed that 1 week of accelerated carbonation exposure for concrete made with PC, CEM II/A (6-20\% LS) and CEM II/B $(21-35 \% \mathrm{LS})$ is equivalent to about $0.58,0.69$ and 0.92 years of natural indoor carbonation exposure, respectively. These values are dissimilar to that suggested by $\mathrm{Ho}$ and Lewis (1987), who proposed a factor of 1.0 with accelerated carbonation at $4 \%$ carbon dioxide concentration. Figure 8 was prepared using these conversion factors and shows trend lines that are similar to the natural indoor carbonation exposure shown in Figure 7(a).

\begin{tabular}{|c|c|c|c|c|c|c|c|c|}
\hline \multirow[b]{3}{*}{ Cement } & \multicolumn{2}{|c|}{ (a) At $37 \mathrm{MPa}$} & \multirow{2}{*}{\multicolumn{2}{|c|}{$\begin{array}{l}\text { (b) At } 25 \mathrm{~mm} \\
\text { cover } \\
\text { Characteristic } \\
\text { strength: } \mathrm{MPa}\end{array}$}} & \multicolumn{2}{|c|}{ (c) At $w / c=0.55$} & \multicolumn{2}{|c|}{$\begin{array}{l}\text { (d) At } 25 \mathrm{~mm} \\
\text { cover }\end{array}$} \\
\hline & \multicolumn{2}{|c|}{ Carbonation depth: mm } & & & \multicolumn{2}{|c|}{ Carbonation depth: mm } & \multicolumn{2}{|c|}{$w / c$ ratio } \\
\hline & Indoor & $\begin{array}{l}\text { Outdoor } \\
\text { sheltered }\end{array}$ & Indoor & $\begin{array}{l}\text { Outdoor } \\
\text { sheltered }\end{array}$ & Indoor & $\begin{array}{l}\text { Outdoor } \\
\text { sheltered }\end{array}$ & Indoor & $\begin{array}{l}\text { Outdoor } \\
\text { sheltered }\end{array}$ \\
\hline CEM I & 30 & 18 & 42 & 20 & 27 & 17 & 0.54 & 0.67 \\
\hline CEM II/A (6-20\% LS) & 33 & 23 & 44 & 34 & 32 & 24 & $0 \cdot 49$ & 0.56 \\
\hline CEM II/B (21-35\% LS) & 39 & 35 & 48 & 45 & 44 & 29 & $0 \cdot 42$ & 0.51 \\
\hline
\end{tabular}

Table 4. Fifty-year extrapolated carbonation depth, characteristic cube strength and $w / c$ ratio of PC and PLC concretes for different design parameters 


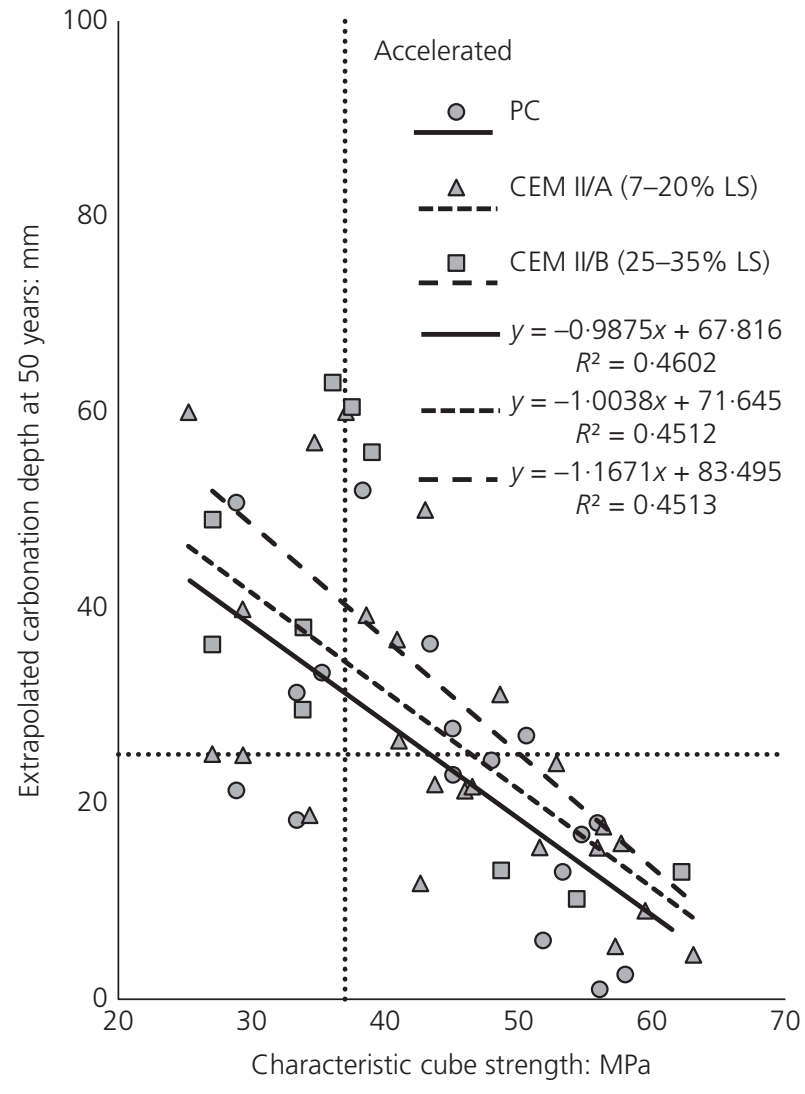

Figure 8. Extrapolated carbonation depth at 50 years of PC and PLC concretes based on accelerated carbonation exposure (3-5\% carbon dioxide concentration) at different characteristic cube strengths

\section{Carbonation depth at specified w/c ratio}

The 50-year expected carbonation depths of concrete with respect to $w / c$ ratio for natural exposure of indoor, outdoor sheltered and outdoor unsheltered conditions are presented in Figures 9(a), 9(b) and 9(c) respectively. The suggested maximum $w / c$ ratio of 0.55 for $\mathrm{XC} 3$ exposure provided by $\mathrm{BS}$ EN 206:2013 (BSI, 2013) and the conforming minimum concrete cover of $25 \mathrm{~mm}$ as specified in Eurocode 2 (BS EN 19921-1:2004+A1:2014 (BSI, 2004)) are also shown in Figure 9. This figure has been developed based on the results used in Figure 3, and in addition the carbonation data of those PLC mixes for which PC control mixes were not adopted by the authors, after they were subject to the selection criterion based on mix limitations for the carbonation exposure.

The relative resistance to carbonation of PC and PLC concretes shown in Figure 9 are similar to that in Figure 7 (with respect to characteristic strength). For comparable carbonation to PC concrete at $0.55 \mathrm{w} / \mathrm{c}$ ratio, as an example, subjected to natural indoor and outdoor sheltered exposures, Figure 9 suggests that the $w / c$ ratio of PLC concrete made with CEM
II/A (6-20\% LS) and CEM II/B (24-35\% LS) need to be reduced by about of 0.06 and $0 \cdot 13$, respectively.

Taking a $w / c$ ratio of 0.55 and a concrete cover of $25 \mathrm{~mm}$, the corresponding carbonation depths and $w / c$ ratios of concrete made with PC and PLC as provided in BS EN 1971:2011 (BSI, 2011) were obtained and are given in Table 4 columns (c) and (d).

The 50-year carbonation depths derived for the accelerated exposure measurements at 3-5\% carbon dioxide concentration, using the established conversion factors of $0.59,0.79$ and 0.90 for PC, CEM II/A (6-20\% LS) and CEM II/B (21-35\% LS), respectively, are shown plotted in Figure 10. Although, similarly to Figure 9, there is considerable scatter within the results, an average conversion factor of 1 week accelerated carbonation is equivalent to 0.75 years of natural indoor exposure and may be adopted for practical convenience.

\section{In situ carbonation measurements}

Guiglia and Taliano (2013) reported the results of an extensive study undertaken involving Italian highway infrastructure. The testing programme covered structures along $135 \mathrm{~km}$ on such different members as piers, abutments, tunnels and walls with the following testing parameters: overall range of age at field measurement $1-5$ years; LS content up to $25 \%$; outdoor sheltered exposure for abutments, piers and tunnels; outdoor unsheltered exposure for walls; range of mean relative humidity, $\mathrm{RH}=64-75 \%$; range of mean in situ core compressive strength $27-45 \mathrm{MPa}$; mean carbonation depth range for a duration of 1 to 5 years, for sheltered and unsheltered exposures, were $3-19 \mathrm{~mm}$ and $2-13 \mathrm{~mm}$, respectively. Although the duration exposure for which the results are reported is short, the majority of the results show that PLC concrete had higher carbonation rates than the $\mathrm{PC}$ concrete for both type of exposures.

However, contrary to the Italian project, in another set of in situ carbonation measurements of concrete road pavements constructed in Canada during 2008-2009, with the carbonation measurements taken at an age of 3-4 years, PC concrete was found to carbonate at a faster rate than PLC concrete (Hossack et al., 2014). Some of the details provided are LS content, $12 \%$; w/c ratio, $0 \cdot 37-0.44$; in situ core strength, 43-59 MPa; outdoor sheltered exposure; measured carbonation within the range of $0 \cdot 5-5 \cdot 0 \mathrm{~mm}$. Clearly some important information is missing and this, together with the early age for which carbonation data is only available, makes the assessment of PLC concrete difficult, if not impossible.

\section{Influence of limestone on carbonation- induced reinforcement corrosion}

The effect of LS addition on carbonation-induced corrosion of reinforcement is an important topic, yet only a few studies 


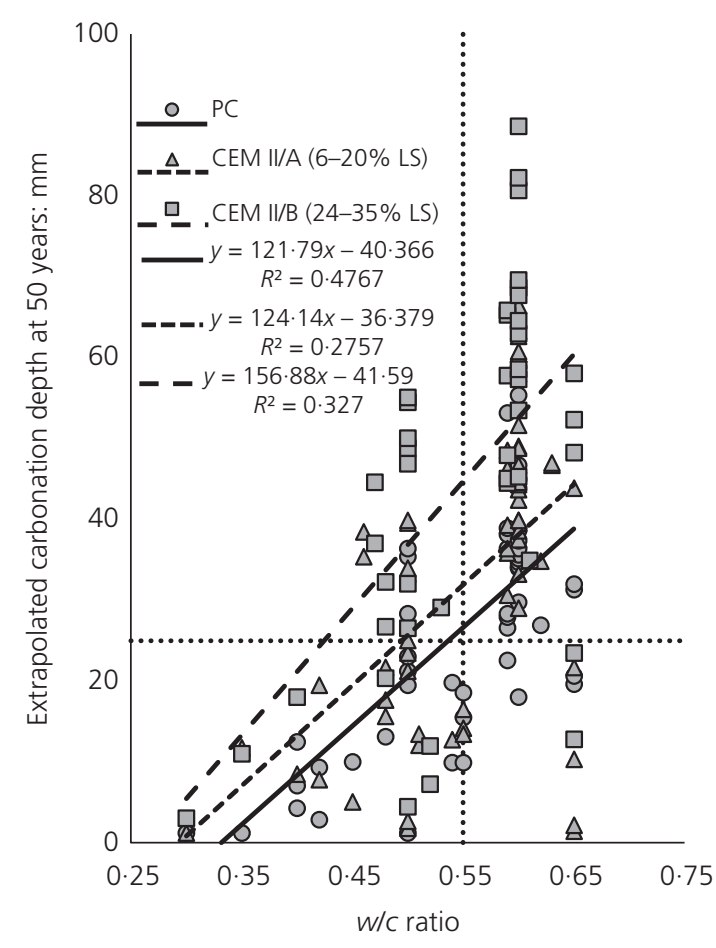

(a)

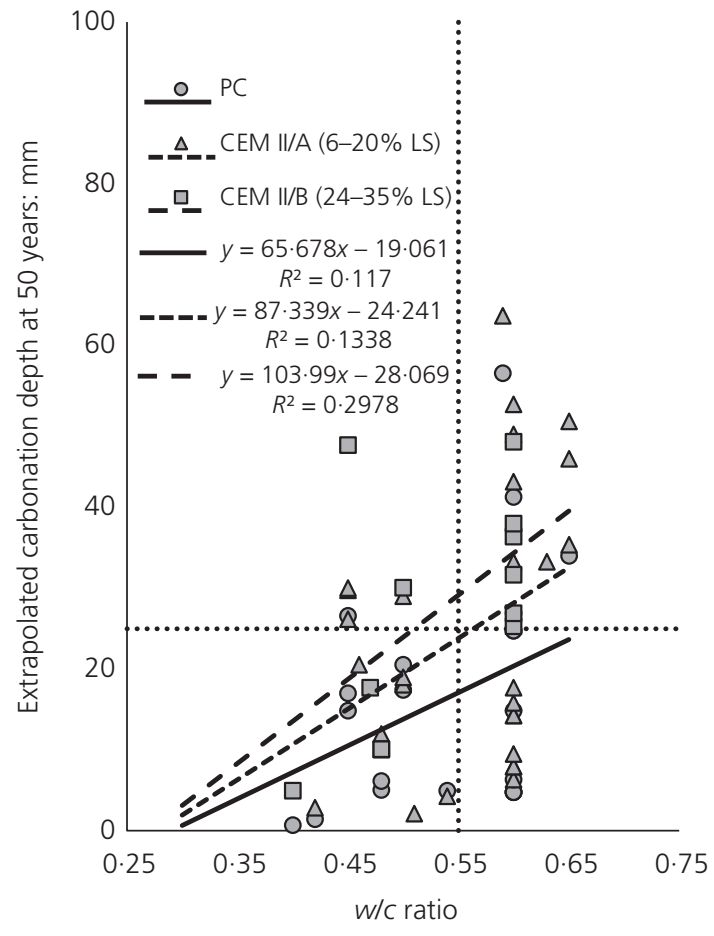

(b)

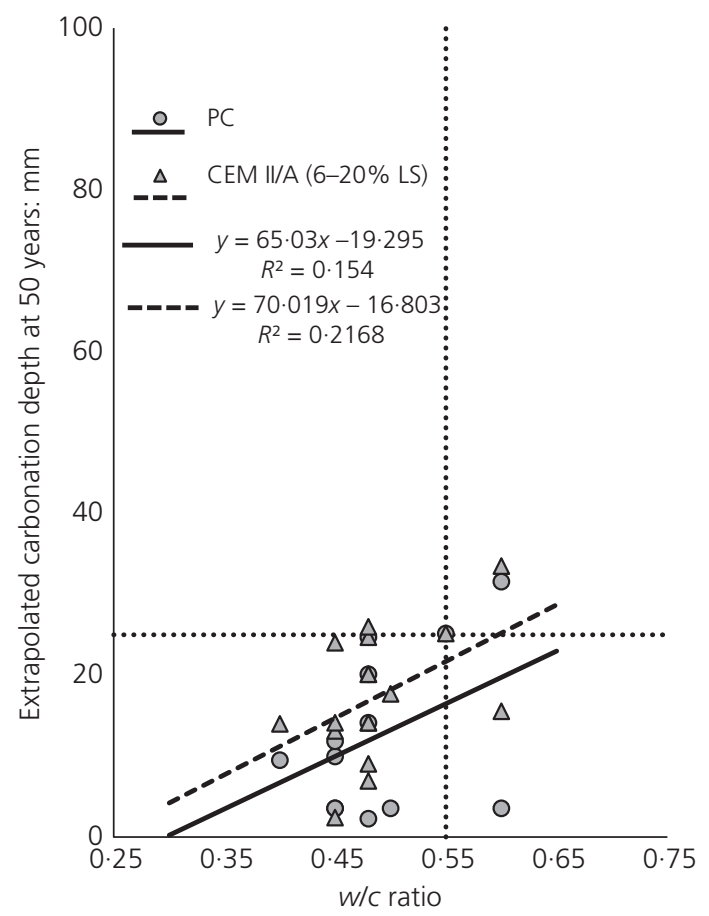

(c)

Figure 9. Extrapolated carbonation depth at 50 years of PC and PLC concretes subjected to natural carbonation exposures: (a) indoor; (b) outdoor sheltered; (c) outdoor unsheltered, at different $w / c$ ratios 


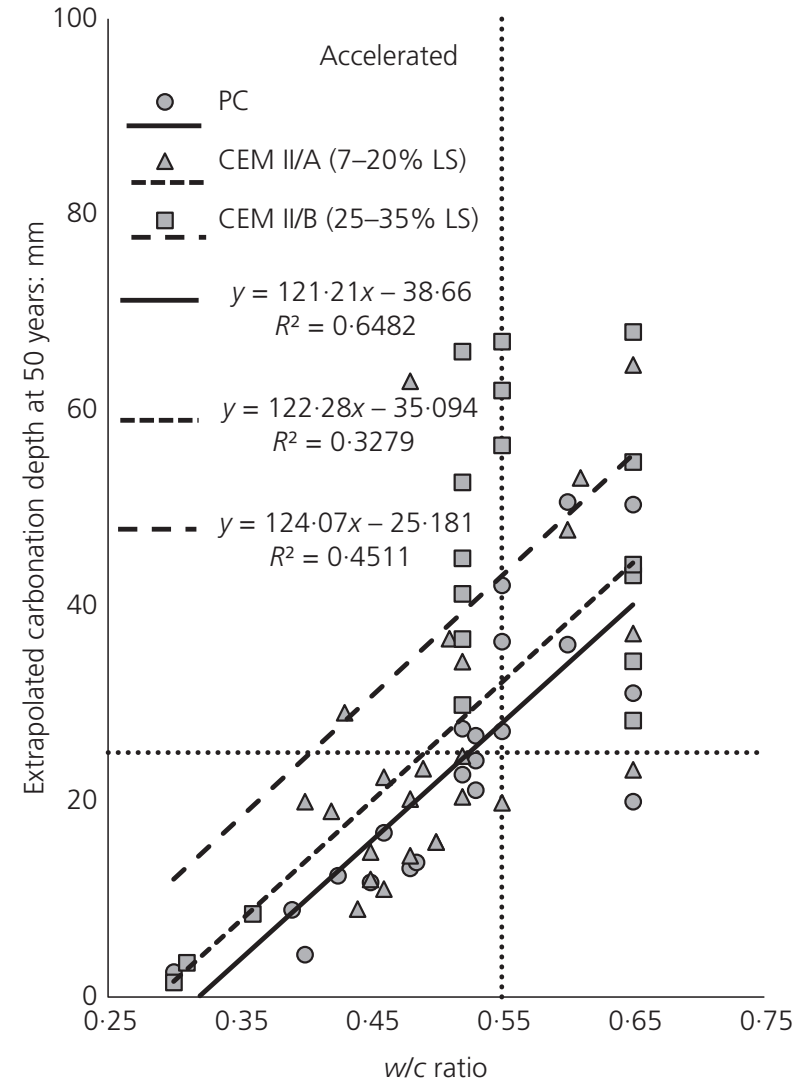

Figure 10. Extrapolated carbonation depth at 50 years of PC and PLC concretes based on accelerated carbonation exposure (3-5\% carbon dioxide concentration) at different $w / c$ ratios

have been found to have reported on the subject. Moreover, based on the expectation that use of LS as a component of cement is likely to increase, and the obvious susceptibility of PLC concrete to carbonation as identified in the previous sections, the effect of LS use on the reinforcement corrosion of concrete can give rise to concern. However, given the limited number of studies (Bolzoni et al., 2006, 2014; Matthews, 1994; Parrott, 1994, 1996; Redaelli and Bertolini, 2011a, 2011b, 2014; Sistonen et al., 2008) reporting on reinforcement corrosion after cover has fully carbonated, and the complexity of the test methodology and the measurements used, the information available in the literature can at present only be examined in a qualitative manner, as summarised in Table 5.

Table 5 shows that, in general, the test specimens were made with cement blends of $0-25 \%$ LS content with $w / c$ ratios of $0 \cdot 55-0.71$ and subjected to natural carbonation exposure for up to 5 years or accelerated carbonation conditions for up to 25 weeks. The corrosion of steel reinforcement was measured in different terms as weight loss of reinforcement $\left(\mathrm{g} / \mathrm{m}^{2}\right)$, corrosion current $\left(\mathrm{mA} / \mathrm{m}^{2}\right)$ and corrosion rate $(\mu \mathrm{m} /$ year). For the studies that have been undertaken, PLC concrete has been found to show a higher rate of reinforcement corrosion than the corresponding PC concrete. The rate of corrosion has been found to be not significantly affected by $w / c$ ratio or the period of moist curing (Parrott, 1994), although some studies have produced conflicting results, showing that the corrosion rate of PLC increases with a rise in the $w / c$ ratio (Redaelli and Bertolini, 2011a, 2011b).

\section{Measures to minimise carbonation effect of PLC concrete}

The effect of LS addition on the carbonation of concrete can be minimised by a number of means. Although increasing the moist curing will certainly help to enhance the resistance of PLC concrete against carbonation by developing a less porous and less permeable concrete, to achieve this in practice can be difficult, owing to present construction practices. Other possible options for improving the carbonation resistance of PLC concrete are listed below.

(a) Restricting the LS addition content to a smaller proportion, namely, to a maximum of $20 \%$. Such a cement will be in compliance with PLC of type CEM II/A (6-20\% LS) as in BS EN 197 (BSI, 2011). Although this option may be used without greatly reducing the carbonation resistance of concrete, it would be less effective in minimising the embodied carbon of the cement industry.

(b) Increasing the specified characteristic strength of concrete by a significant reduction in its $w / c$ ratio using a high-range water-reducing admixture. This option should enhance the durability and sustainability characteristics of concrete (Dhir et al., 2000, 2004, 2006).

(c) Increasing the thickness of concrete cover could be considered as an additional obvious choice. Nevertheless, this will impact structural design and sustainability aspects, and is unlikely to be preferred by the design engineer.

\section{Comparison of carbonation resistance of concrete made with PLC, FA and GGBS}

This is the third paper in the series of studies planned to assess the effect of cement additions on the resistance to carbonation of concrete, where the first two have dealt with the effect of FA (Lye et al., 2015) and GGBS (Lye et al., 2016). To facilitate a meaningful comparison in the performance of the three major additions, all adopted by EN 197-1 (BSI, 2011) for use in concrete as a component of cement, as mentioned before, the same methodology and formatting have been adopted for each of the studies in the series. Figure 11 and Figure 12 and Tables 6 and 7 summarise their relative performance, as discussed below.

\section{Replacement effect}

At the same replacement level, and in a concrete of the same composition, FA can be expected to give the highest 
(a) Studies where PLC concrete is assessed alongside PC reference concrete

Matthews (1994)

Corrosion rate of PLC concrete was higher than that of PC concrete

Reinforcement corrosion measurement: percentage rebar weight loss; range of PC results:

$0 \cdot 14-0 \cdot 19$; range of PLC (5\% LS) results: $0 \cdot 15-0 \cdot 21$; range of PLC (25\% LS) results:

$0 \cdot 32-0.45$

Prism specimen: $100 \times 100 \times 300 \mathrm{~mm}$; concrete cover: $10 \mathrm{~mm}$; LS contents: 0,5 and $25 \%$; w/c ratio: 0.60; moist curing: 28 d; exposure: natural outdoor unsheltered; duration: 5 years; equal $w / c$ mix

Parrott (1994) Corrosion rate of PLC concrete was slightly higher than that of PC concrete and was not significantly affected by $w / c$ ratio and curing duration

Reinforcement corrosion measurement: rebar weight loss $\left(\mathrm{g} / \mathrm{m}^{2}\right)$; range of PC results: 9-17 $\mathrm{g} / \mathrm{m}^{2}$; range of PLC (5\% LS) results: $11-19 \mathrm{~g} / \mathrm{m}^{2}$

Cube specimen: $100 \times 100 \times 100 \mathrm{~mm}$; concrete cover: $4 \mathrm{~mm}$; LS contents: 0 and $5 \%$; W/c ratio: 0.59-0.71; moist curing: 3 and 545 d; exposure: natural indoor, outdoor sheltered and outdoor unsheltered; duration: 4 years; equal $w / c$ mix

Parrott (1996) Corrosion rate of PLC concrete was higher than that of PC concrete

Reinforcement corrosion measurement: rebar weight loss $\left(\mathrm{g} / \mathrm{m}^{2}\right)$; range of PC results: $7-11 \mathrm{~g} / \mathrm{m}^{2}$; range of PLC (15\% LS) results: $8-15 \mathrm{~g} / \mathrm{m}^{2}$; range of PLC (19\% LS) results: $15-26 \mathrm{~g} / \mathrm{m}^{2}$; range of PLC (25\% LS) results: $21-30 \mathrm{~g} / \mathrm{m}^{2}$

Cube specimen: $100 \times 100 \times 100 \mathrm{~mm}$; concrete cover: $4 \mathrm{~mm}$; LS contents: 0, 15, 19 and 25\%; w/c ratio: 0.60; moist curing: 1-28 d; exposure: natural indoor; duration, 1.5 years; equal $w / c$ mix

(b) Studies where only PLC concrete has been assessed

Bolzoni et al., $(2006,2014) \quad$ The steel rebar of PLC concrete exhibited a high corrosion rate

Reinforcement corrosion measurement: corrosion rate through linear polarisation resistance method ( $\mu \mathrm{m} /$ year), PLC result: $12 \mu \mathrm{m} /$ year

Prism specimen: $200 \times 250 \times 50 \mathrm{~mm}$; concrete cover: $20 \mathrm{~mm}$; LS content: $14 \%$; w/c ratio: 0.60; moist curing: $28 \mathrm{~d}$; carbon dioxide: $10 \%$; temperature: $25^{\circ} \mathrm{C} ; \mathrm{RH}: 65 \%$, duration: 25 weeks

Redaelli and Bertolini (2014) The corrosion rate of PLC concrete was considered to be on the moderate level Reinforcement corrosion measurement: corrosion current $\left(\mathrm{mA} / \mathrm{m}^{2}\right)$, PLC result: $4 \mathrm{~mA} / \mathrm{m}^{2}$ Prism specimen: $40 \times 40 \times 160 \mathrm{~mm}$; concrete cover: $15 \mathrm{~mm}$; LS content: $13 \%$; w/c ratio: 0.65 ; moist curing: $7 \mathrm{~d}$; carbon dioxide: $2 \%$; temperature: $21^{\circ} \mathrm{C}$; $\mathrm{RH}: 65 \%$, duration: 6 weeks

Redaelli and Bertolini (2011a, 2011b)

The corrosion rate results of PLC concrete reflected high activity and increased with increasing W/c ratio

Reinforcement corrosion measurement: corrosion current $\left(\mathrm{mA} / \mathrm{m}^{2}\right)$, range of PLC results: $15-18 \mathrm{~mA} / \mathrm{m}^{2}$

Cylinder specimen: $60 \times 300 \mathrm{~mm}$; concrete cover: $25 \mathrm{~mm}$; LS content: 15\%; w/c ratio: 0.55-0.70; moist curing: $7 \mathrm{~d}$; carbon dioxide: $6 \%$; temperature: $20^{\circ} \mathrm{C} ; \mathrm{RH}: 60 \%$, duration: 18 weeks

Sistonen et al. (2008) The corrosion rate results for PLC concrete indicated active corrosion Reinforcement corrosion measurement: corrosion current $\left(\mathrm{mA} / \mathrm{m}^{2}\right), \mathrm{PLC}$ result: $16 \mathrm{~mA} / \mathrm{m}^{2}$ Cylinder specimen: $44 \times 200 \mathrm{~mm}$; concrete cover: 15-19 mm; LS content: 13\%; w/c ratio: 0.70; air curing: $21 \mathrm{~d}$; carbon dioxide: $7 \%$; temperature: $22^{\circ} \mathrm{C}$; $\mathrm{RH}: 75 \%$, duration: 10 weeks

Table 5. Summary of influence of LS addition on carbonation induced corrosion

rate of carbonation followed by LS and GGBS, see Figure 11. This can be explained in terms of the reactivity of each of the three additions and the consumption of calcium hydroxide $\left(\mathrm{Ca}(\mathrm{OH})_{2}\right)$. However, given that GGBS is usually used at a much higher replacement level, depending upon the actual replacement level, in practice the carbonation of concrete with the use of GGBS may be higher than that with LS and FA. 


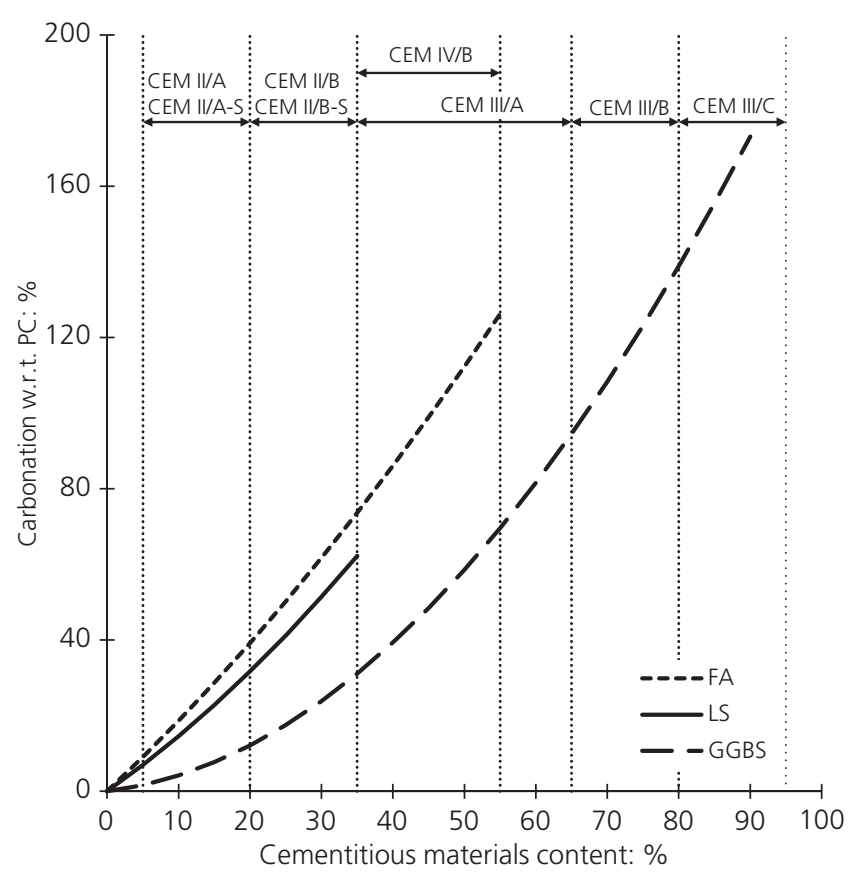

Figure 11. Comparison of LS, FA and GGBS concretes; effect of replacement

\section{Fifty-year extrapolated carbonation depth}

The estimated 50-year carbonation depth of PLC, FA and GGBS concretes designed on an equal strength basis (Figures 12(a) and 12(b)) is lower than that of concretes based on an equal $w / c$ ratio basis (Figures $12(\mathrm{c})$ and 12(d)). Taking the minimum concrete cover of $25 \mathrm{~mm}$ and $w / c$ ratio of 0.55 or characteristic cube strength of $37 \mathrm{MPa}$ as per BS EN 206 (BSI, 2013), for indoor exposure conditions, all concretes (reference PC, PLC, FA and GGBS) are likely to surpass the adopted cover before the time period of 50 years (Figures 12(a) and 12(c)). Nevertheless, for outdoor sheltered exposure conditions, this minimum concrete cover is

(a) adequate for concrete made with

(i) CEM I,

(ii) CEM II/A (6-20\% LS),

(iii) CEM II/A (6-20\% FA)

(iv) CEM II/B-S (21-35\% GGBS)

(b) not adequate for concrete made with:

(i) CEM II/B (21-35\% LS)

(ii) $\mathrm{CEM} \mathrm{II/B}(21-35 \%$ FA)

(iii) $\mathrm{CEM}$ IV/B $(36-55 \% \mathrm{FA})$

(iv) CEM III/A (36-65\% GGBS)

(v) $\mathrm{CEM} \mathrm{III/B} \mathrm{(66-80 \%} \mathrm{GGBS).}$

\section{Mix design adjustment for similar carbonation}

In order to obtain comparable carbonation to PC concrete, the concrete mix design adjustment made in terms of reduction in $w / c$ ratio or increase in compressive strength for PLC and FA concretes will be more than for GGBS concrete at the same replacement level (Table 6).

\section{Accelerated and natural indoor carbonation relationship}

Although the relationship for the natural indoor and accelerated carbonation of concrete developed for PLC in this study and for FA and GGBS by (Lye et al., 2015, 2016) are dissimilar (Table 7), for practical purposes, a conversion factor of 1 week of accelerated carbonation (at 3-5\% carbon dioxide concentration) can be assumed to be equivalent to 0.65 years of natural indoor carbonation.

\section{Conclusions}

(a) In general, combinations of LS with PC, similar to the range in BS EN 197-1 (BSI, 2011), lead to increased carbonation. The degree of this increase depends on the composition of concrete in terms of its $w / c$ ratio and strength, maturity and pore structure as it is subjected to carbonation.

(b) Carbonation measurements relative to the corresponding $\mathrm{PC}$ concrete suggest that the depth of carbonation increases with LS content, giving an increase of the order of $50 \%$ with $30 \%$ LS content, which is similar to PLC type CEM II/B in BS EN 197:2011 (BSI, 2011).

(c) For PLC concrete designed in terms of equal strength or equal $w / c$ ratio to PC concrete, the carbonation of PLC concrete designed on the basis of equal $w / c$ ratio is higher than that designed on an equal strength basis, for both natural and accelerated carbonation exposures. This difference in the performance of the two sets of PLC mixes can be narrowed with the use of finer LS and/or extended moist curing of concrete mixes designed on the equal $w / c$ ratio basis. PLC mixes designed on an equal strength basis and exposed to a prolonged moist curing can attain a carbonation resistance near to that of PC concrete.

(d) In studying the estimated 50 years' carbonation of concrete with respect to its strength, $w / c$ ratio and cover, in compliance with the mix limits of BS EN 206-1:2013 (BSI, 2013) for the carbonation exposure classes, outdoor unsheltered exposure was found to cause the lowest carbonation and indoor the highest. Additionally, the results showed that, for a certain exposure class and specified strength and $w / c$ ratio, the required thickness of concrete cover increases as the LS content of the cement is increased. On the other hand, for a particular cover, the required strength increases and $w / c$ ratio decreases with the LS content of the cement.

(e) One week of accelerated carbonation of PLC concrete, at $3-5 \%$ carbon dioxide concentration, was found to be 


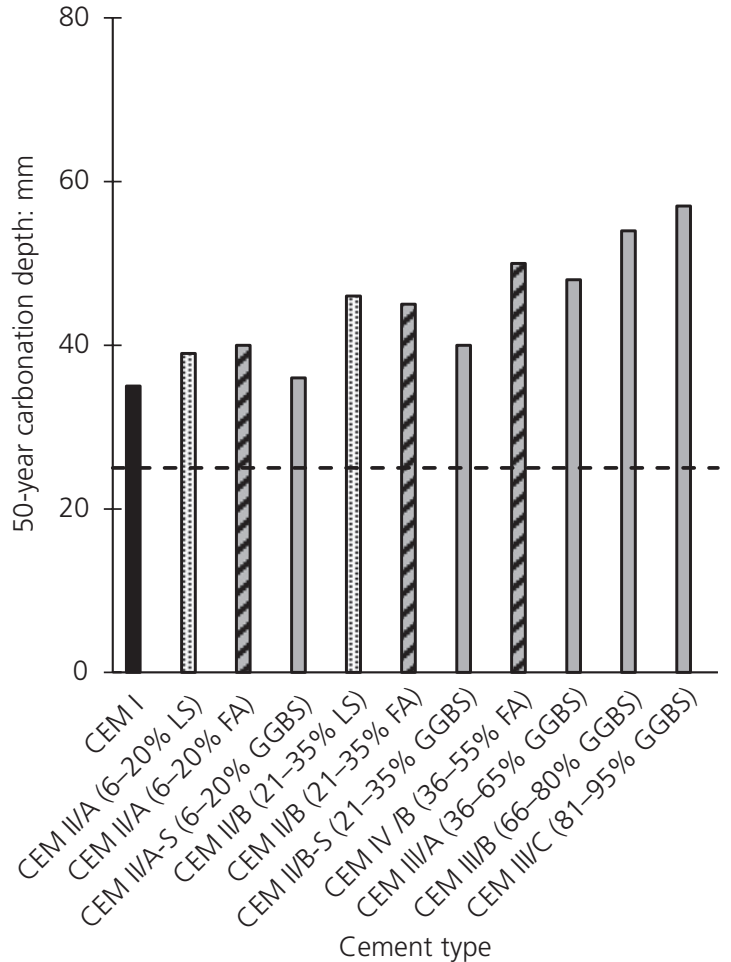

(a)

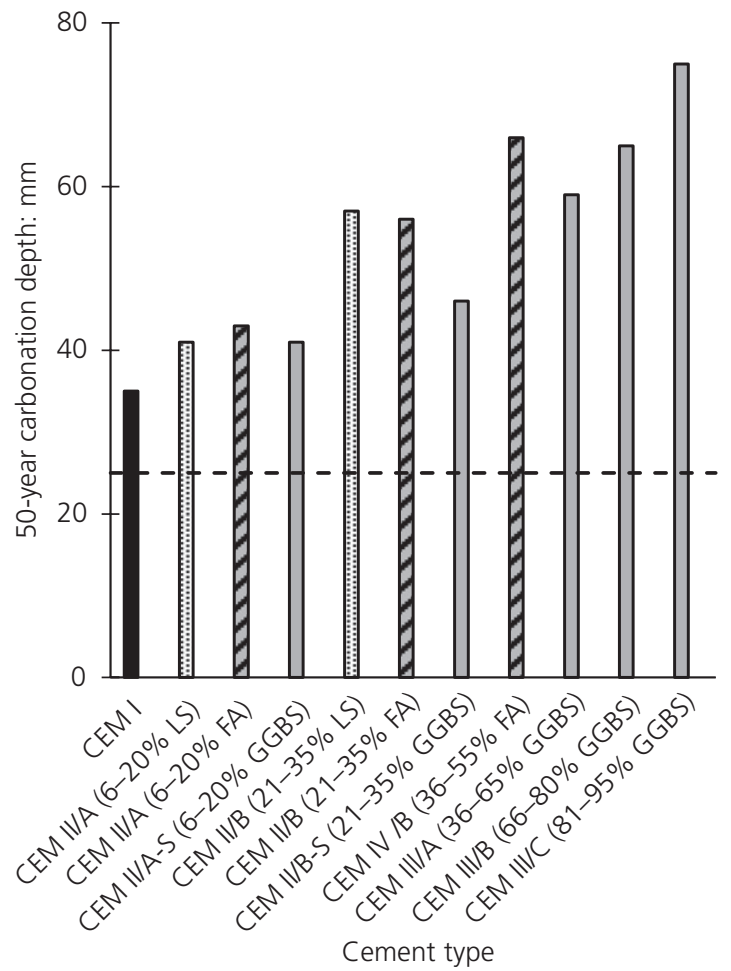

(c)

Figure 12. Comparison of 50-year estimated carbonation depth for LS, FA and GGBS concretes. Note: Data normalised so that the 50-year estimated carbonation of PC reference in PLC, FA and GGBS results is similar under the same carbonation exposure and

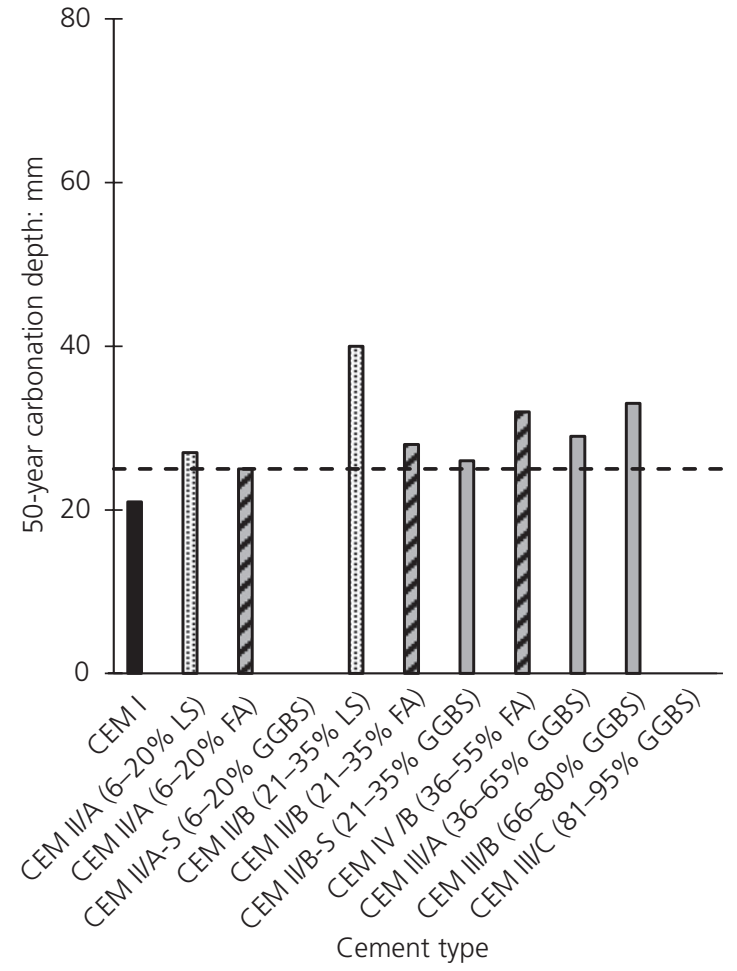

(b)

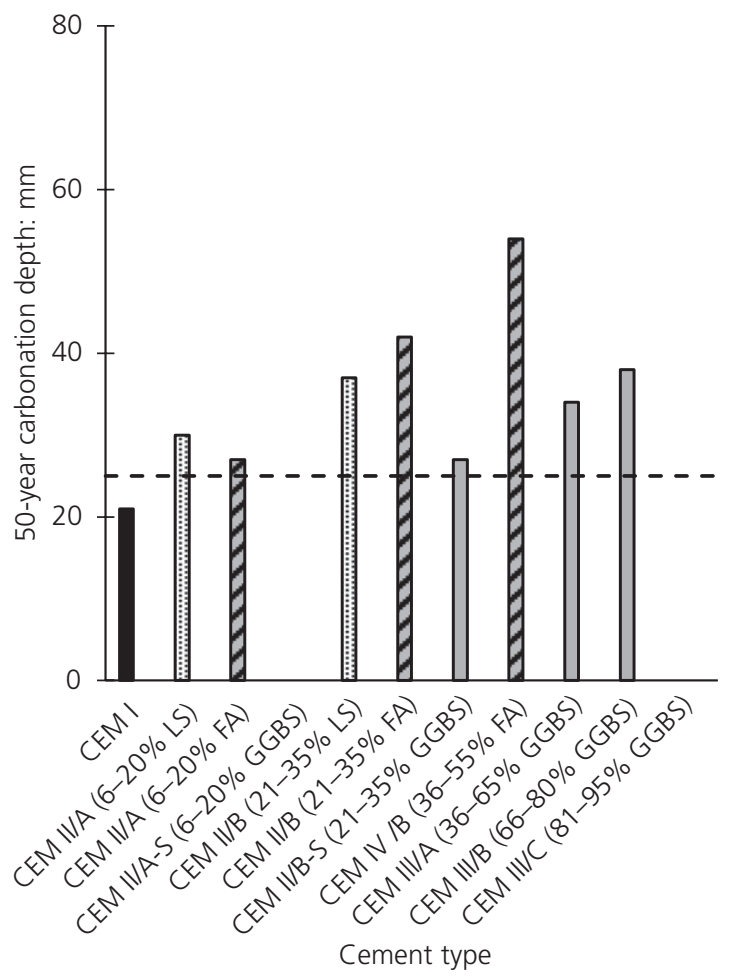

(d)

data for CEM II/A (6-20\% GGBS) and CEM III/C (81-95\% GGBS) under outdoor carbonation not available: (a) at $37 \mathrm{MPa}$, indoor; (b) at $37 \mathrm{MPa}$, outdoor sheltered; (c) at $w / \mathrm{c}=0.55$, indoor; (d) at $w / c=0 \cdot 55$, outdoor sheltered 


\begin{tabular}{lcc} 
Cement & \multicolumn{2}{c}{$\begin{array}{c}\text { Mix adjustment for similar } \\
\text { carbonation }\end{array}$} \\
\cline { 2 - 3 } & $\begin{array}{c}\text { Additional } \\
\text { strength, } \text { MPa }^{a}\end{array}$ & $\begin{array}{c}\text { W/c } \\
\text { reduction }\end{array}$ \\
\hline CEM I & $0 \cdot 0$ & $0 \cdot 0$ \\
CEM II/A (6-20\% LS) & $5 \cdot 5$ & $0 \cdot 06$ \\
CEM II/A (6-20\% FA) & $5 \cdot 0$ & $0 \cdot 05$ \\
CEM II/A-S (6-20\% GGBS) & $n / a$ & $n / a$ \\
CEM II/B (21-35\% LS) & $10 \cdot 5$ & $0 \cdot 13$ \\
CEM II/B (21-35\% FA) & $7 \cdot 5$ & $0 \cdot 15$ \\
CEM II/B-S (21-35\% GGBS) & $5 \cdot 5$ & $0 \cdot 10$ \\
CEM IV/B (36-55\% FA) & $10 \cdot 0$ & $0 \cdot 25$ \\
CEM III/A (36-65\% GGBS) & $9 \cdot 5$ & $0 \cdot 20$ \\
CEM III/B (66-80\% GGBS) & 13.0 & $0 \cdot 22$ \\
\end{tabular}

${ }^{\mathrm{a} P C}$ at $37 \mathrm{MPa}$

${ }^{\mathrm{b} P C}$ at $0.55 \mathrm{~W} / \mathrm{c}$

Table 6. Comparison of PLC, FA and GGBS concretes, mix adjustment for similar carbonation

\begin{tabular}{lc}
\hline $\begin{array}{l}\text { Cement } \\
\text { type }\end{array}$ & $\begin{array}{c}\text { Duration equivalent to } 1 \text { week accelerated } \\
\text { exposure: years }\end{array}$ \\
\hline PLC & $0.58-0.92$ \\
FA & $0.38-0.54$ \\
GGBS & $0.60-0.65$
\end{tabular}

Table 7. Relationship between accelerated and indoor carbonation for PLC, FA and GGBS concretes

about equivalent to 0.75 years of natural indoor exposure.

( $f$ ) The rate of corrosion in PLC concrete, upon carbonation reaching the reinforcement, was found to be higher than that in PC concrete.

(g) In-situ carbonation measurements of 1-5 years of concrete structures made with PC and PLC showed that although the carbonation varies with exposure conditions, PLC concrete is likely to carbonate at a faster rate than the corresponding $\mathrm{PC}$ concrete.

(h) In order to lower the carbonation influence of PLC on structural concrete, consideration should be given to restricting the addition of LS, and increasing the target strength and/or the thickness of concrete cover.

Nonetheless, these measures must be assessed alongside the other design requirements of durability and sustainability.

(i) Comparing the carbonation performance of concrete made with PLC with concrete made with cement containing FA (Lye et al., 2015) and GGBS (Lye et al., 2016), the main points to note are given below.

Similarities: Concrete made with cement containing PLC, FA and GGBS carbonates at a higher rate than concrete made with PC, and this increase is higher for concrete designed on an equal $w / c$ ratio basis than on an equal strength basis. The minimum concrete cover suggested for a characteristic cube strength of $37 \mathrm{MPa}$ or $w / c$ ratio of 0.55 as stated in Eurocode 2 for $\mathrm{XC} 3$ exposure needs to be reviewed for concrete containing LS, FA and GGBS.

Differences: As in practice GGBS is generally used in structural concrete at a considerably higher level than FA or LS, it can be expected to be at a higher risk than PLC and FA concretes. The accelerated indoor carbonation relationship of concrete differs for LS, FA and GGBS materials, but even so, for ease of use, a figure of 1 week of accelerated carbonation equals 0.65 years of natural indoor exposure has been proposed.

\section{REFERENCES}

Abualgasem JM, Cripps JC and Lynsdale CJ (2014) Effects of wetting and drying cycles on thaumasite formation in cement mortars. Journal of Materials in Civil Engineering 27(7): B4014006-1-6.

ACl (American Concrete Institute) (2005) ACI 301-05: Specifications for structural concrete. American Concrete Institute, Farmington Hills, MI, USA.

Ali A and Dunster A (1998) Durability of Reinforced Concrete: Effects of Concrete Composition and Curing on Carbonation Under Different Exposure Conditions. Building Research Establishment Ltd., Garston, UK; CRC.

Alunno-Rosetti $V$ and Curcio F (1997) A contribution to the knowledge of the properties of Portland-limestone cement concretes, with respect to the requirements of European and Italian design code. Proceedings of the 10th International Congress on the Chemistry of Cement, Gothenburg, Sweden, vol. 3, pp. 26-32.

Assie S, Escadeillas G, Marchese G and Waller V (2006) Durability properties of low-resistance self-compacting concrete. Magazine of Concrete Research 58(1): 1-7, http://dx.doi.org/10.1680/macr.2006.58.1.1.

Assie S, Escadeillas G and Waller V (2007) Estimates of selfcompacting concrete 'potential' durability. Construction and Building Materials 21(10): 1909-1917.

Ayub T, Shafiq N, Khan SU and Nuruddin M (2013) Durability of concrete with different mineral admixtures: a review. International Journal of Civil, Structural, Construction and Architectural Engineering 7(8): 265-276.

Balayssac JP, Détriché CH and Grandet J (1995) Effects of curing upon carbonation of concrete. Construction and Building Materials 9(2): 91-95.

Balcu I, Dencsak T and Bob C (2012) Tests for the determination of carbon dioxide uptake by concrete carbonation. 
fib Symposium 2012: Concrete Structures for Sustainable Community - Proceedings, Stockholm, Sweden, pp. 59-62.

Barker AP and Matthews JD (1994) Concrete durability specification by water/cement or compressive strength for European cement types. In Durability of Concrete: Proceedings of 3rd CANMET-ACI International Conference, Nice, France (Malhotra VM (ed.)). American Concrete Institute, Farmington Hills, MI, USA, Special Publication 145, pp. 1135-1160.

Baron PJ (1986) The durability of limestone composite cements in the context of the French specifications. In Durability of Concrete: Aspects of Admixtures and Industrial by Products, Proceedings of International Seminar (Nilsson LO (ed.)). Swedish Council of Building Research, Stockholm, Sweden, pp. 115-122.

Batic OR, Sota JD, Fernández JL, Bellotti N and Romagnoli R (2013) Rebar corrosion in mortars with high limestone filler content. Anti-Corrosion Methods and Materials 60(1): 3-13.

Bertolini L, Lollini F and Redaelli E (2007) Influence of concrete composition on parameters related to the durability of reinforced concrete structures. Proceeding of the International Rilem Workshop: Integral Service Life Modelling of Concrete Structures, Guimarães, Portugal, pp. 56-64.

Bertolini L, Carsana M and Redaelli E (2008) Conservation of historical reinforced concrete structures damaged by carbonation induced corrosion by means of electrochemical realkalisation. Journal of Cultural Heritage 9(4): 376-385.

Bertolini L, Lollini F and Redaelli E (2009) Experimental data for the application of performance-based methods for the design of reinforced concrete structures subjected to carbonation. In Special Topics on Materials Science and Technology - An Italian Panorama (Acierno D, D'Amore A, Caputo D and Cioffi R (eds)). Brill, Leiden, The Netherlands, pp. 55-64.

Bertrandy R and Poitevin P (1991) Limestone filler for concrete, French research and practice. Blended Cements in Construction, Proceedings of International Conference, Sheffield, UK, pp. 16-31.

Bolzoni F, Goidanich S, Lazzari L and Ormellese M (2006) Corrosion inhibitors in reinforced concrete structures part 2-repair system. Corrosion Engineering, Science and Technology 41(3): 212-220.

Bolzoni F, Brenna A, Fumagalli G et al. (2014) Experiences on corrosion inhibitors for reinforced concrete. International Journal of Corrosion and Scale Inhibition 3(4): 254-278.

BSI (2002) BS EN 1990:2002+A1:2005: Eurocode - basis of structural design. BSI, London, UK.

BSI (2004) BS EN 1992-1-1:2004+A1:2014: Eurocode 2: design of concrete structures. Part 1-1: general rules and rules for buildings. BSI, London, UK.
BSI (2011) EN 197-1:2011: Cement. Composition specifications and conformity criteria for common cement. BSI, London, UK.

BSI (2013) EN 206:2013: Concrete. Specification, performance, production and conformity. BSI, London, UK.

Cangiano S and Princigallo A (2010) Using dealuminated metakaolin in concrete as microsilica substitute. Proceedings of 2nd International Conference on Sustainable Construction Materials and Technologies, Ancona, Italy, vol. 3, pp. 43-52.

Catinaud S, Beaudoin JJ and Marchand J (2000) Influence of limestone addition on calcium leaching mechanisms in cement-based materials. Cement and Concrete Research 30(12): 1961-1968.

Chowaniec O and Scrivener KL (1992) Durability aspects of cement with high limestone filler content. Proceedings of the 9th International Congress of the Chemistry of Cement, New Delhi, India, pp. 53-59.

Collepardi M, Collepardi S, Olagot JO and Simonelli F (2004a) The influence of slag and fly ash on the carbonation of concrete. Proceedings of the 8th CANMET/ACI International Conference on Fly Ash, Silica Fume, Slag, and Natural Pozzolans in Concrete, Las Vegas, NV, USA, pp. 23-29.

Corinaldesi V and Moriconi G (2004) Durable fiber reinforced self-compacting concrete. Cement and Concrete Research 34(2): 249-254.

Courard L and Michel F (2014) Limestone fillers cement based composites: effects of blast furnace slags on fresh and hardened properties. Construction and Building Materials 51: 439-445.

Courard L, Degeimbre R, Darimont A et al. (2005) Some effects of limestone fillers as a partial substitute for cement in mortar composition. Proceedings of ConMat'05 3rd International Conference on Construction Materials: Performance, Innovations and Structural Implications, Vancouver, BC, Canada, pp. 22-32.

CSWP (Concrete Society Working Party) (2011) Cementitious Materials. The Effect of GGBS, Fly Ash, Silica Fume and Limestone Fines on the Properties of Concrete. Concrete Society, Camberley, UK, Technical Report 74.

Detwiler RJ and Tennis PD (1996) The Use of Limestone in Portland Cement: a State-of-the-Art Review. Portland Cement Association, Skokie, IL, USA, No. RP118, RP118. 02T.

Dhir RK, Tittle PAJ and Mccarthy MJ (2000) Role of cement content in specifications for durability of concrete $-\mathrm{a}$ review. Concrete 34(10): 68-76.

Dhir RK, McCarthy MJ, Zhou S and Tittle PAJ (2004) Role of cement content in specifications for concrete durability: cement type influences. Proceedings of the Institution of Civil Engineers - Structures and Buildings 157(2): 113-127.

Dhir RK, McCarthy MJ, Tittle PA and Zhou S (2006) Role of cement content in specifications for concrete 
durability: aggregate type influences. Proceedings of the Institution of Civil Engineers - Structures and Buildings 159(4): 229-242, http://dx.doi.org/10.1680/stbu.2006. 159.4.229.

Dhir RK, Limbachiya MC, McCarthy MJ and Chaipanich A (2007) Evaluation of Portland limestone cements for use in concrete construction. Materials and Structures 40(5): 459-473.

Diamanti MV, Lollini F, Pedeferri MP and Bertolini L (2013) Mutual interactions between carbonation and titanium dioxide photoactivity in concrete. Building and Environment 62: 174-181.

Drouet E, Poyet S, Le Bescop P and Torrenti JM (2010) Chemical changes and carbonation profiles of carbonated cement pastes at $80 \mathrm{C}$ for different relative humidities. Proceedings of 6th International Conference on Concrete under Severe Conditions: Environment and Loading, Merida, Yucatan, Mexico, pp. 321-328.

El-Hassan $\mathrm{H}$ and Shao Y (2015) Early carbonation curing of concrete masonry units with Portland limestone cement. Cement and Concrete Composites 62: 168-177.

Figueiras H, Nunes S, Coutinho JS and Figueiras J (2009) Combined effect of two sustainable technologies: selfcompacting concrete (SCC) and controlled permeability formwork (CPF). Construction and Building Materials 23(7): 2518-2526.

Franzoni E, Pigino B and Pistolesi C (2013) Ethyl silicate for surface protection of concrete: performance in comparison with other inorganic surface treatments. Cement and Concrete Composites 44: 69-76.

Frazão C, Camões A, Barros J and Gonçalves D (2015a) Durability of steel fiber reinforced self-compacting concrete. Construction and Building Materials 80: 155-166.

Frazão C, Camões A, Barros J and Gonçalves D (2015b) Durability of steel fiber reinforced self-compacting concrete. Proceedings of Twin Covilhã International Conferences, 5th International Conference on the Concrete Future, Covilhã, Portugal, pp. 93-102.

Galan I, Andrade C, Mora P et al. (2010a) $\mathrm{CO}_{2}$ sink effect of concrete carbonation. Proceedings of 2nd International Conference on Sustainable Construction Materials and Technologies, Ancona, Italy, vol. 14, pp. 143-153.

Galan I, Andrade C, Mora P et al. (2010b) Sequestration of $\mathrm{CO}_{2}$ by concrete carbonation. Environmental Science and Technology 44(8): 3181-3186.

Galan I, Andrade C and Castellote M (2012)

Thermogravimetrical analysis for monitoring carbonation of cementitious materials. Journal of Thermal Analysis and Calorimetry 110(1): 309-319.

Guiglia M and Taliano M (2013) Comparison of carbonation depths measured on in-field exposed existing RC structures with predictions made using fib-model code 2010. Cement and Concrete Composites 38: 92-108.

Hawkins P, Tennis PD and Detwiler RJ (2003) The Use of Limestone in Portland Cement: a State-of-the-Art Review. Portland Cement Association, Skokie, IL, USA, p. 44.
Ho DWS and Lewis RK (1987) Carbonation of concrete and its prediction. Cement and Concrete Research 17(3): 489-504.

Holt EE, Kousa HP, Leivo MT and Vesikari EJ (2009)

Deterioration by frost, chloride and carbonation interactions based on combining field station and laboratory results. Proceedings of 2nd International Rilem Workshop on Concrete Durability and Service Life Planning, Haifa, Israel, pp. 123-130.

Holt E, Kuosa H, Leivo M et al. (2010) Accounting for coupled deterioration mechanisms for durable concrete containing mineral by-products. Proceedings of 2nd International Conference on Sustainable Construction Materials and Technologies, Ancona, Italy, vol. 3, pp. 1631-1643.

Hooton RD, Nokken M and Thomas MDA (2007) PortlandLimestone Cement: State-of-the-art Report and Gap Analysis for CSA A 3000. Cement Association of Canada, University of Toronto, Toronto, Canada.

Hossack A, Thomas MD, Barcelo L, Blair B and Delagrave A (2014) Performance of Portland limestone cement concrete pavements. Concrete International 36(1): 40-45.

Hussain K, Choktaweekarn P, Saengsoy W, Srichan T and Tangtermsirikul S (2013) Effect of cement types, mineral admixtures, and bottom ash on the curing sensitivity of concrete. International Journal of Minerals, Metallurgy, and Materials 20(1): 94-105.

Ingram KD and Daugherty KE (1992) Limestone additions to Portland cement: uptake, chemistry, and effects. Proceedings of 9th International Congress on the Chemistry of Cement, New Delhi, India, vol. 3, pp. 180-186.

Kaewmanee K and Tangtermsirikul S (2014) Properies of binder systems containing cement, fly ash, and limestone powder. Songklanakarin Journal of Science and Technology 36(5): 569-576.

Kargol MA, Müller U and Gardei A (2013) Properties and performance of silane: blended cement systems. Materials and Structures 46(9): 1429-1439.

Kjellsen KO, Guimaraes $\mathrm{M}$ and Nilsson A (2005) The $\mathrm{CO}_{2}$ Balance of Concrete in a Life Cycle Perspective. Nordic Innovation Centre Project, Oslo, Norway.

Krell J (1989) Influence of additions on the relation between durability and strength. In Proceedings of ERMCO '89, the Norway to Concrete, Stavanger, Norway (Fluge F, Hunsbedt OS and Injar J (eds)). European Ready Mixed Concrete Organisation, Brussels, Belgium, pp. 645-650.

Kuosa H, Vesikari E, Holt E and Leivo M (2008) Field and laboratory testing and service life modeling in Finland. Proceedings of Nordic Concrete Research Workshop, Hirtshals, Denmark, pp. 181-208.

Kuosa H, Leivo M and Holt E (2012) Effect of varying surface ageing on frost-salt scaling. In Bridge Maintenance, Safety, Management, Resilience and Sustainability (Biondi F and Frangopol DM (eds)). Taylor \& Francis Group, London, UK, pp. 974-981.

Kuosa H, Ferreira RM, Holt E, Leivo M and Vesikari E (2014) Effect of coupled deterioration by freeze-thaw, carbonation 
and chlorides on concrete service life. Cement and Concrete Composites 47: 32-40.

Lagerblad B (2005) Carbon Dioxide Uptake During Concrete Life Cycle - State of the Art. Swedish Cement and Concrete Research Institute CBI, Stockholm, Sweden, pp. $1-48$.

Leemann A, Nygaard P, Kaufmann J and Loser R (2015) Relation between carbonation resistance, mix design and exposure of mortar and concrete. Cement and Concrete Composites 62: $33-43$

Livesey P (1991) Performance of limestone-filled cements. Blended Cements in Construction, Proceedings of International Conference, Sheffield, UK, pp. 1-15.

Lollini F, Redaelli E and Bertolini L (2014) Effects of Portland cement replacement with limestone on the properties of hardened concrete. Cement and Concrete Composites $\mathbf{4 6}$ : 32-40.

Lye CQ, Dhir RK and Ghataora GS (2015) Carbonation resistance of fly ash concrete. Magazine of Concrete Research 67(21): 1150-1178, http://dx.doi.org/10.1680/macr.15.00204.

Lye CQ, Dhir RK and Ghataora GS (2016) Carbonation resistance of GGBS concrete. Magazine of Concrete Research 68(18): 936-969, http://dx.doi.org/10.1680/jmacr.15.00449.

Manns W, Thielen G and Laskowski C (2001) Evaluation of the Results of Tests for Building Inspectorate Approval of Portland Limestone Cements. Verein Deutscher Zementwerke (VDZ), Dusseldorf, Germany, Concrete Technology Report, pp. 15-24.

Marques PF, Chastre C and Nunes Â (2013) Carbonation service life modelling of RC structures for concrete with Portland and blended cements. Cement and Concrete Composites 37: $171-184$.

Matthews JD (1994) Performance of limestone filler cement concrete. In Euro-Cements: Impact of ENV 197 on Concrete Construction (Dhir RK and Jones MR (eds)). E \& FN Spon, London, UK, pp. 113-147.

Mayfield LL (1990) Limestone additions to Portland cement an old controversy revisited. In Carbonate Additions to Cement (Klieger P and Hooton RD (eds)). ASTM International, West Conshohocken, PA, USA, STP 1064, pp. 3-13.

McNally C and Sheils E (2012) Probability-based assessment of the durability characteristics of concretes manufactured using CEM II and GGBS binders. Construction and Building Materials 30: 22-29.

Meddah MS, Lmbachiya MC and Dhir RK (2014) Potential use of binary and composite limestone cements in concrete production. Construction and Building Materials 58: 193-205.

Meira GR, Andrade C, Vilar EO and Nery KD (2014) Analysis of chloride threshold from laboratory and field experiments in marine atmosphere zone. Construction and Building Materials 55: 289-298.

Moir GK and Kelham S (1993) Durability 1. Performance of Limestone-Filled Cements: Report of Joint
BRE/BCA/Cement Industry Working Party. BRE, Garston, UK, pp. 7.1-7.78.

Moir GK and Kelham S (1999) Developments in the manufacture and use of Portland limestone cement. In High-Performance Concrete, Proceedings of ACI International Conference (Malhotra VM (ed.)). American Concrete Institute, Farmington Hills, MI, USA, ACI SP 172 , pp. $797-820$.

Müller C (2012) Use of cement in concrete according to European standard EN 206-1. HBRC Journal 8(1): 1-7.

Müller C and Lang E (2006) Durability of concrete made with Portland-limestone and Portland composite cements CEM II-M (S-LL). Beton 55: 131-138.

Müller C, Palm S, Graubner C A et al. (2014) Cements with a high limestone content - durability and practicability. Cement International 12(2): 78-85.

Mwaluwinga S, Ayano T and Sakata K (1997) Influence of urea in concrete. Cement and Concrete Research 27(5): 733-745.

Neves R, da Fonseca BS, Branco F et al. (2015) Assessing concrete carbonation resistance through air permeability measurements. Construction and Building Materials 82: 304-309.

Nielsen P, Nicolai S, Darimont A and Kestemont X (2014) Influence of cement and aggregate type on thaumasite formation in concrete. Cement and Concrete Composites 53: 115-126.

Nieuwoudt P, Zaffaroniand P and Pistolesi C (2012) Case history of polymer-modified cementitious membrane used to protect new and repair concrete. Concrete Repair, Rehabilitation and Retrofitting III, Proceedings of 3rd International Conference on Concrete Repair, Rehabilitation and Retrofitting, ICCRRR-3, Cape Town, South Africa, pp. 932-937.

Owsiak Z and Grzmil W (2015) The evaluation of the influence of mineral additives on the durability of self-compacting concretes. KSCE Journal of Civil Engineering 19(4): $1002-1008$.

Parrott LJ (1994) A study of carbonation-induced corrosion. Magazine of Concrete Research 46(166): 23-28, http://dx.doi.org/10.1680/macr.1994.46.166.23.

Parrott LJ (1996) Some effects of cement and curing upon carbonation and reinforcement corrosion in concrete. Materials and Structures 29(3): 164-173.

Perlot C, Rougeau P and Dehaudt S (2013) Slurry of metakaolin combined with limestone addition for self-compacted concrete. Application for precast industry. Cement and Concrete Composites 44: 50-57.

Phung QT, Maes N, Jacques D et al. (2015) Effect of limestone fillers on microstructure and permeability due to carbonation of cement pastes under controlled $\mathrm{CO}_{2}$ pressure conditions. Construction and Building Materials 82: 376-390.

Pomeroy CD (1993) ENV 197 Cements: Perspective in Relation to EC2 and ENV 206. Performance of Limestone-Filled 
Cements: Report of Joint BRE/BCA/Cement Industry Working Party. BRE, Garston, UK, pp. 10.1-10.15.

Proske T, Hainer S, Rezvani M and Graubner CA (2013) Eco-friendly concretes with reduced water and cement contents - mix design principles and laboratory tests. Cement and Concrete Research 51: 38-46.

Proske T, Hainer S, Rezvani M and Graubner CA (2014)

Eco-friendly concretes with reduced water and cement content-mix design principles and application in practice. Construction and Building Materials 67: 413-421.

Rabehi M, Mezghiche B and Guettala S (2013) Correlation between initial absorption of the cover concrete, the compressive strength and carbonation depth. Construction and Building Materials 45: 123-129.

Ranc R, Moranville-Regourd M, Cochet G and Chaudouard G (1991) Durability of cements with fillers. In Durability of Concrete, Proceedings of 2nd International Conference, Montreal, Canada (Malhotra VM (ed.)). CANMET/American Concrete Institute, Farmington Hills, MI, USA, Special Publication 126, vol. II, pp. 1239-1257.

Redaelli E and Bertolini L (2011a) Electrochemical repair techniques in carbonated concrete. Part I: electrochemical realkalisation. Journal of Applied Electrochemistry 41(7): 817-827.

Redaelli E and Bertolini L (2011b) Electrochemical repair techniques in carbonated concrete. Part II: cathodic protection. Journal of Applied Electrochemistry 41(7): 829-837.

Redaelli E and Bertolini L (2014) Durability aspects of electrochemical realkalisation treatment. In Concrete Solutions (Grantham M, Muhammed Basheer PA, Magee B and Soutsos M (eds)). CRC Press, Taylor \& Francis Group, London, UK, pp. 215-221.

Révay M and Gável V (2003) Thaumasite sulphate attack at the concrete structures of the Ferenc Puskás stadium in Budapest. Cement and Concrete Composites 25(8): 1151-1155.

Rio O, Nguyen VD and Nguyen K (2015) Exploring the potential of the functionally graded SCCC for developing sustainable concrete solutions. Journal of Advanced Concrete Technology 13(3): 193-204.

Rostami V, Shao Y, Boyd AJ and He Z (2012) Microstructure of cement paste subject to early carbonation curing. Cement and Concrete Research 42(1): 186-193.

Rozière E and Loukili A (2011) Performance-based assessment of concrete resistance to leaching. Cement and Concrete Composites 33(4): 451-456.

Schmidt M (1992a) Cement with interground additives capabilities and environmental relief: II. $Z K G$ International, Edition B 45(6): 296-301.

Schmidt M (1992b) Cement with interground additives capabilities and environmental relief: I. ZKG International, Edition B 45(2): 64-69.
Schmidt M, Harr K and Boing R (1993) Blended cement according to ENV 197 and experiences in Germany. Cement, Concrete, and Aggregates, CCAGDP 15(2): 156-164.

Segura I, Molero M, Aparicio S, Anaya JJ and Moragues A (2013) Decalcification of cement mortars: characterisation and modelling. Cement and Concrete Composites 35(1): 136-150.

Shao Y, Rostami V, He Z and Boyd AJ (2014) Accelerated carbonation of Portland limestone cement. Journal of Materials in Civil Engineering 26(1): 117-124.

Shi Z, Geiker MR, De Weerdt K et al. (2015) Durability of Portland cement blends including calcined clay and limestone: interactions with sulfate, chloride and carbonate ions. In Calcined Clays for Sustainable Concrete (Scrivener K and Favier A (eds)). Springer, Dordrecht, the Netherlands, pp. 133-141.

Silva PR and de Brito J (2016) Durability performance of self-compacting concrete (SCC) with binary and ternary mixes of fly ash and limestone filler. Materials and Structures 49(7): 1-18.

Sistonen E, Cwirzen A and Puttonen J (2008) Corrosion mechanism of hot-dip galvanised reinforcement bar in cracked concrete. Corrosion Science 50(12): 3416-3428.

Sprung S and Siebel E (1991) Assessment of the suitability of limestone for producing Portland limestone cement. $Z K G$ International, Edition B 44(1): 1-11.

Tennis PD, Thomas MDA and Weiss WJ (2011) State-of-the-art Report on Use of Limestone in Cements at Levels of up to 15\%. Portland Cement Association, Skokie, IL, USA, pp. 10-20.

Tezuka Y, Gomes D, Martins JM and Djanikian JG (1992) Durability aspects of cements with high limestone filler content. Proceedings of the 9th International Congress on the Chemistry of Cement, New Delhi, India, vol. 5, pp. 53-59.

Thenepalli T, Jun AY, Han C, Ramakrishna C and Ahn JW (2015) A strategy of precipitated calcium carbonate $(\mathrm{CaCO} 3)$ fillers for enhancing the mechanical properties of polypropylene polymers. Korean Journal of Chemical Engineering 32(6): 1009-1022.

Thienel KC and Beuntner N (2012) Effects of calcined clay as low carbon cementing materials on the properties of concrete. Proceedings of the 8th International Conference: Concrete in the Low Carbon Era, Dundee, UK, vol. 9, No. 11.7 , pp. 504-517.

Thomas MD and Hooton RD (2010) The Durability of Concrete Produced with Portland-limestone Cement: Canadian Studies. Portland Cement Association, Skokie, IL, USA.

Thomas MD, Delagrave A, Blair B and Barcelo L (2013) Equivalent durability performance of Portland limestone cement. Concrete International 35(12): 39-45.

Torgal FP, Miraldo S, Labrincha JA and De Brito J (2012) An overview on concrete carbonation in the context of 
eco-efficient construction: evaluation, use of SCMs and/or RAC. Construction and Building Materials 36: 141-150.

Tschegg EK, Bohner E, Tritthart J and Müller HS (2011) Investigations into fracture of carbonated concrete. Magazine of Concrete Research 63(1): 21-30, http:// dx.doi.org/10.1680/macr.2011.63.1.21.

Tsivilis S, Batis G, Chaniotakis E, Grigoriadis G and Theodossis D (2000) Properties and behavior of limestone cement concrete and mortar. Cement and Concrete Research 30(10): 1679-1683.

Tsivilis S, Chaniotakis E, Kakali G and Batis G (2002) An analysis of the properties of Portland limestone cements and concrete. Cement and Concrete Composites 24(3): 371-378.

Vandanjon PO, De Larrard F, Dehousse B et al. (2003) Homogenisation of concrete in a batch plant: the influence of mixing time and method on the introduction of mineral admixtures. Magazine of Concrete Research 55(2): 105-116, http://dx.doi.org/10.1680/ macr.2003.55.2.105.

Ylmen R and Jäglid U (2013) Carbonation of Portland cement studied by diffuse reflection fourier transform infrared spectroscopy. International Journal of Concrete Structures and Materials 7(2): 119-125.

\section{HOW CAN YOU CONTRIBUTE?}

To discuss this paper, please submit up to 500 words to the editor at journals@ice.org.uk. Your contribution will be forwarded to the author(s) for a reply and, if considered appropriate by the editorial board, it will be published as a discussion in a future issue of the journal. 